\title{
Article \\ HER2-Targeted Immunotherapy and Combined Protocols Showed Promising Antiproliferative Effects in Feline Mammary Carcinoma Cell-Based Models
}

\author{
Andreia Gameiro, Catarina Nascimento $(\mathbb{D}$, Jorge Correia $(\mathbb{B})$ and Fernando Ferreira *(i) \\ CIISA - Centro de Investigação Interdisciplinar em Sanidade Animal, Faculdade de Medicina Veterinária, \\ Universidade de Lisboa, Avenida da Universidade Técnica, 1300-477 Lisboa, Portugal; \\ agameiro@fmv.ulisboa.pt (A.G.); catnasc@fmv.ulisboa.pt (C.N.); jcorreia@fmv.ulisboa.pt (J.C.) \\ * Correspondence: fernandof@fmv.ulisboa.pt; Tel.: +351-21-365-2800 (ext. 431234)
}

Citation: Gameiro, A.; Nascimento, C.; Correia, J.; Ferreira, F. HER2-Targeted Immunotherapy and Combined Protocols Showed

Promising Antiproliferative Effects in Feline Mammary Carcinoma Cell-Based Models. Cancers 2021, 13, 2007. https://doi.org/10.3390/ cancers 13092007

Academic Editors:

Mohammad Hojjat-Farsangi and Afshin Namdar

Received: 3 March 2021

Accepted: 19 April 2021

Published: 21 April 2021

Publisher's Note: MDPI stays neutral with regard to jurisdictional claims in published maps and institutional affiliations.

Copyright: (c) 2021 by the authors. Licensee MDPI, Basel, Switzerland This article is an open access article distributed under the terms and conditions of the Creative Commons Attribution (CC BY) license (https:// creativecommons.org/licenses/by/ $4.0 /)$.
Simple Summary: Mammary tumors are common in cats, presenting an aggressive behavior with high tumor recurrence. Therefore, new and efficient therapeutic protocols are urgent. Monoclonal antibodies (mAbs; ADC) are widely used in human breast cancer therapy, inhibiting the HER2 dimerization and leading to cell apoptosis. Furthermore, drug combinations, with tyrosine kinase inhibitors (TKi) are valuable in patients' therapeutic protocols. In this study, two mAbs, and an ADC, as well as combined protocols between $\mathrm{mAbs}$ and $\mathrm{mAbs}$ plus lapatinib (TKi) were tested to address if the drugs could be used as new therapeutic options in feline mammary tumors. All the compounds and the combined treatments revealed valuable antiproliferative effects, and a conserved cell death mechanism, by apoptosis, in the feline cell lines, where the mutations found in the extracellular domain of the HER2 suggest no immunotherapy resistance.

Abstract: Feline mammary carcinoma (FMC) is a highly prevalent tumor, showing aggressive clinicopathological features, with HER2-positive being the most frequent subtype. While, in human breast cancer, the use of anti-HER2 monoclonal antibodies (mAbs) is common, acting by blocking the extracellular domain (ECD) of the HER2 protein and by inducing cell apoptosis, scarce information is available on use these immunoagents in FMC. Thus, the antiproliferative effects of two mAbs (trastuzumab and pertuzumab), of an antibody-drug conjugate compound (T-DM1) and of combined treatments with a tyrosine kinase inhibitor (lapatinib) were evaluated on three FMC cell lines (CATMT, FMCm and FMCp). In parallel, the DNA sequence of the her2 ECD (subdomains II and IV) was analyzed in 40 clinical samples of FMC, in order to identify mutations, which can lead to antibody resistance or be used as prognostic biomarkers. Results obtained revealed a strong antiproliferative effect in all feline cell lines, and a synergistic response was observed when combined therapies were performed. Additionally, the mutations found were not described as inducing resistance to therapy in breast cancer patients. Altogether, our results suggested that anti-HER2 mAbs could become useful in the treatment of FMC, particularly, if combined with lapatinib, since drug-resistance seems to be rare.

Keywords: feline mammary carcinoma; HER2; monoclonal antibodies; combined therapies; tyrosine kinase inhibitors; feline her2 mutations

\section{Introduction}

Similarly to human breast cancer [1], the feline mammary carcinoma (FMC) is a very common tumor [2], presenting different molecular subtypes [3], being the feline HER2-positive, the most prevalent one (33-60\%) [2,4]. The HER2-overexpression occurs associated to an AKT activation [5], both markers of a poor prognosis and a high metastatic potential [2,6]. In cats, a lack of therapeutic options lead most of the time to surgery [7], 
the development of different therapeutic strategies being urgent in order to improve the clinical outcome.

The epidermal growth factor receptor 2 (HER2) is a common target in patients with HER2-overexpression tumors [8]. HER2 is a transmembrane glycoprotein, which modulates cell proliferation, differentiation and survival $[9,10]$. This protein is composed by three domains: an extracellular domain (ECD), a short transmembrane region and an intracellular tyrosine kinase (TK) activity domain [9]. Considering the ECD, it comprises four subdomains, I and II that are the membrane distal regions, and III and IV that are the membrane proximal regions, allowing protein-protein interaction and stabilization $[9,11]$. Since a sequence identity of $92 \%$ was reported between the human and feline her $2[12,13]$, the use of monoclonal antibodies (mAbs) in the feline mammary carcinoma could be an alternative and attractive therapeutic approach.

Nowadays, the use of mAbs are widely common in HER2-positive breast cancer patients, decreasing its downstream pathways activation, such as AKT and mTOR, responsible for the antiapoptotic mechanisms [5], cell cycle progression and cell proliferation [14], important checkpoints in the carcinogenesis process [5]. For example, trastuzumab [15-17] is a monoclonal IgG antibody that inhibits HER2 homodimerization [18], blocking the HER2 pathway. This antibody prevents the receptor internalization and its degradation, stimulating antibody-dependent cellular cytotoxicity (ADCC) responses [19] and promoting cell apoptosis [20,21]. Trastuzumab resistance is documented in $40 \%$ of metastatic patients [22], due to changes in the HER2 expression status [23] and structure [24,25], or other EGFRs pathway's activators [26-28]. In parallel, another mAb commonly used is pertuzumab, a recombinant IgG1 antibody anti-HER2 [15,29], valuable in combined therapeutic protocols [30]. This mAb inhibits the heterodimerization HER2-HER3 [18], inactivating the PI3K pathway and its downstream signaling cascades [31]. This compound also stimulates ADCC [32], leading to cell-cycle arrest and apoptosis [33]. However, specific mutations can lead to pertuzumab resistance [34,35]. More recently, another compound in clinical use for breast cancer treatment is trastuzumab-emtansine (T-DM1) [36], which is an antibody-drug conjugate (ADC), consisting of the humanized monoclonal trastuzumab antibody covalently linked to the cytotoxic tubulin-binding agent (DM1) [37]. T-DM1 mechanism is associated to trastuzumab-HER2 conjugation and the release of the DM1 molecule after complex degradation into lysosomes [38]. The efficacy of this drug depends on the cell membrane HER2 concentration [39] and allows to decrease the systemic cytotoxic effects of DM1, by its specific delivery to the tumor HER2-overexpression cells [38,39], triggering autophagy and apoptosis [40]. T-DM1 leads to the inhibition of HER2 ECD shedding and PI3K/AKT pathway, stimulates ADCC, mitotic arrest, and disruption of the intracellular trafficking. Additionally, for this compound, several different mechanisms of resistance are described, not only associated with the HER2 protein, as well as STAT3 activation [41], defective cyclin B1 induction [42] and multidrug resistance proteins [39].

In human breast cancer, $50 \%$ of the HER2-positive patients show immunotherapy resistance [43], the combined therapeutic protocols being truly valuable [44]. Frequently used trastuzumab plus pertuzumab $[18,28,44,45]$ leads to a synergistic response and increased ADCC effects [31,46]. Another common combination is the use of mAbs with tyrosine kinase inhibitors (TKi), which are small molecules that bind to the cytoplasmic catalytic kinase domain of the HER2, preventing tyrosine phosphorylation and signaling [43], such as lapatinib [47-49].

An early diagnosis and individual therapy is crucial for the improvement of survival time [50] and prevention of therapy resistance in cats with mammary carcinoma [43]. Thus, this study aims to: (1) evaluate the antiproliferative effects of the mAbs (trastuzumab and pertuzumab) and of the T-DM1 in three feline carcinoma cell lines (CAT-MT, FMCm and FMCp); (2) characterize the HER2 expression in the feline cell lines and identify the existence of genomic mutations in the feline her2 ECD (subdomains II and IV); (3) describe the cell death mechanism induced by the mAbs and T-DM1, in the carcinoma cell lines; (4) evaluate the synergistic antiproliferative effects by the combination of mAbs 
(trastuzumab plus pertuzumab) and assess the increase in the cytotoxic response by the use of mAbs with the TKi (lapatinib); (5) identify genomic mutations in the feline her2 gene ECD (subdomains II and IV) in FMC clinical samples, in order to recognize possible therapy resistant animals, or prognostic factors.

\section{Materials and Methods}

\subsection{Feline and Human Mammary Carcinoma Cell Lines}

In this study, three feline cell lines (CAT-MT from the European Collection of Authenticated Cell Culture, England; FMCp and FMCm kindly provided by Prof. Nobuo Sasaki and Prof. Takayuki Nakagawa, University of Tokyo, Japan) [5,51] and a positive control, the HER2-overexpressing human breast cancer cell line (SKBR-3 from the American Type Culture Collection, Manassas, VA, USA) were used, after characterized by immunocytochemistry (Figure S1 and Table S1). Cell cultures were maintained at $37^{\circ} \mathrm{C}$, in a humidified atmosphere of 5\% $(v / v) \mathrm{CO}_{2}$ (Nuaire, Plymouth, MN, USA), in Dulbecco's Modified Eagle Medium (DMEM; Corning, New York, NY, USA), for CAT-MT and SKBR-3, whereas FMCm and FMCp cell lines were maintained in Roswell Park Memorial Institute 1640 Medium (RPMI; Corning), both supplemented with heat-inactivated 20\% (v/v) fetal bovine serum (FBS; Corning). Periodically, all cell lines were inspected to control their morphology and proliferation rate, being tested for Mycoplasma (MycoSEQ ${ }^{\mathrm{TM}}$ Mycoplasma Detection Kit, Thermo Fischer Scientific, Waltham, MA, USA).

\subsection{In Vitro Cytotoxicity Assays}

Viability assays were performed to determine the antiproliferative effects of trastuzumab, pertuzumab and T-DM1 (all from Roche, Basel, Switzerland), using the Cell Proliferation Reagent WST-1 (Abcam, Cambridge, United Kingdom) and following the manufacturer's instructions. Briefly, cell lines were seeded in 96-well plates to obtain a confluency of $90 \%$, after $24 \mathrm{~h}\left(5 \times 10^{3}\right.$ cells/well for CAT-MT and FMCp, $15 \times 10^{3}$ cells/well for FMCm and $10 \times 10^{3}$ cells/wells for SKBR-3), and then exposed to increasing concentrations of each antibody (Table 1), with the control wells left unexposed. Phosphate buffered saline (PBS; Corning) was used as a vehicle for mAbs and ADC. After $72 \mathrm{~h}$ of exposure, the WST-1 reagent (Abcam) was added, followed by an incubation period of $4 \mathrm{~h}$, at $37^{\circ} \mathrm{C}$, and absorbance was measured at $440 \mathrm{~nm}$ using a plate reader (FLUOStar Optima, BMG LabTech, GmbH, Ortenberg, Germany). Triplicate wells were used to determine each data point and three independent experiments were performed.

Table 1. Concentrations of trastuzumab $(\mu \mathrm{g} / \mathrm{mL})$, pertuzumab $(\mu \mathrm{g} / \mathrm{mL})$ and T-DM1 $(\mu \mathrm{g} / \mathrm{mL})$ used in the cytotoxicity assays. Cells were exposed to drug for $72 \mathrm{~h}$ and the antiproliferative effects were evaluated.

\begin{tabular}{ccc}
\hline \multicolumn{3}{c}{ Drug Concentrations for the Cytotoxicity Assays $(\mu \mathrm{g} / \mathbf{m L})$} \\
\hline Trastuzumab & Pertuzumab & T-DM1 \\
\hline 25 & 50 & 5 \\
50 & 100 & 12.5 \\
125 & 250 & 25 \\
250 & 500 & 50 \\
500 & 1000 & 100 \\
1000 & 2000 & 200 \\
2000 & 5000 & 500 \\
5000 & 10,000 & 1000 \\
10,000 & & \\
\hline
\end{tabular}

For the combined assays: trastuzumab plus pertuzumab, trastuzumab plus lapatinib (Sigma-Aldrich, Darmstadt, Germany) and pertuzumab plus lapatinib, a similar methodology was used, testing concentrations that covers different cytotoxic responses (Table 2). 
Table 2. Concentrations of trastuzumab $(\mu \mathrm{g} / \mathrm{mL})$, pertuzumab $(\mu \mathrm{g} / \mathrm{mL})$ and lapatinib $(\mu \mathrm{g} / \mathrm{mL})$ used in the combined treatments. Cells were exposed to drug for $72 \mathrm{~h}$ before cytotoxicity evaluation.

\begin{tabular}{ccc}
\hline \multicolumn{3}{c}{ Drug Concentrations for the Combined Treatments $(\mu \mathrm{g} / \mathrm{mL})$} \\
\hline Trastuzumab & Pertuzumab & Lapatinib \\
\hline 125 & 250 & 0.453 \\
500 & 2000 & 7.26 \\
\hline
\end{tabular}

\subsection{Assessment of HER2 Expression Status by Immunocytochemistry (ICC)}

Expression analysis of HER2 was performed, as reported by us [4,52], in the three feline cell lines (CAT-MT, FMCm and FMCP), and using the human SKBR-3 cell line as a positive control. Briefly, cells were grown till confluency in a T25 culture flask and then were removed and embedded in a histogel matrix (Thermo Fischer Scientific). Cytoblocks were sectioned in slices with $3 \mu \mathrm{m}$ thickness (Microtome Leica RM135, Newcastle, UK) and mounted on a glass slide (SuperFrost Plus, Thermo Fisher Scientific). On PT-Link module (Dako, Agilent, Santa Clara, CA, USA) samples were deparaffinized, hydrated and antigen retrieval was performed for $20 \mathrm{~min}$ at $96^{\circ} \mathrm{C}$, using citrate buffer $\mathrm{pH}$ 6.1 (EnVision ${ }^{\mathrm{TM}}$ Flex Target Retrieval Solution Low pH, Dako). Then, slides were cooled for $30 \mathrm{~min}$ at room temperature (RT) and immersed twice in distilled water for $5 \mathrm{~min}$. ICC technique was performed with commercial solutions from the EnVision ${ }^{\mathrm{TM}}$ FLEX+, Mouse kit (Dako). Before antibody incubation, samples were treated with Peroxidase Block Novocastra Solution (Leica Biosystems) for $15 \mathrm{~min}$. Afterwards, samples were incubated with a primary antibody anti-HER2 (clone CB11, 1:100, ab8054; Abcam) by $1 \mathrm{~h}$ at RT, in a humidified chamber. Then, the EnVision ${ }^{\mathrm{TM}}$ FLEX+ Mouse Linker was incubated by $30 \mathrm{~min}$ and slides were washed for $5 \mathrm{~min}$, between all the incubation steps, using PBS at pH 7.4. Later on, the EnVision ${ }^{\mathrm{TM}}$ FLEX/HRP was incubated for $30 \mathrm{~min}$ at RT, and detection was performed using diaminobenzidine (DAB substrate buffer and DAB Chromogen, Dako) for $5 \mathrm{~min}$. Finally, samples were counterstained with Gill's hematoxylin (Merck, Darmstadt, Germany) for $5 \mathrm{~min}$, dehydrated in an ethanol gradient and xylene, and mounted using Entellan mounting medium (Merck).

HER2 immunoreactivity was scored as recommended by the American Society of Clinical Oncology's (ASCO) [53], and as previously published for feline cells [2,4]. Briefly, the staining intensity was evaluated and classified as HER2-negative when scored 0 and HER2-positive if scored $1+, 2+$ or $3+$ (Table 3). Three microscopic fields were analyzed at $400 \times$ magnification. All samples were subjected to a blind scoring, by two independent pathologists.

Table 3. HER2 immunocytochemistry scoring criteria.

\begin{tabular}{cc}
\hline Score & Interpretation \\
\hline 0 & No staining \\
\hline $1+$ & Weak, incomplete membrane staining \\
\hline $2+$ & $\begin{array}{c}\text { Complete membrane staining, with obvious } \\
\text { circumferential distribution in at least 10\% of } \\
\text { cells, that has either no uniform or is weak in } \\
\text { intensity }\end{array}$ \\
\hline $3+$ & $\begin{array}{c}\text { Uniform and intense membrane staining, at a } \\
\text { minimum of } 10 \% \text { of the tumor cells }\end{array}$ \\
\hline
\end{tabular}

\subsection{Flow Cytometry Assay}

The flow cytometry assay was performed as already reported by us [52]. For this experiment, the cells were seeded in 24-well plates to obtain a confluency of $90 \%$ after $24 \mathrm{~h}\left(5 \times 10^{4}\right.$ cells/well for CAT-MT and FMCp, $10 \times 10^{4}$ cells/well for FMCm, and $7 \times 10^{4}$ cells/well for SKBR-3 cell lines), and then were exposed to mAbs and to the 
$\mathrm{ADC}$ for $72 \mathrm{~h}$, at a concentration close to the $\mathrm{EC}_{50}$ value. Control wells were left unexposed, with the PBS used as a vehicle, in three independent experiments. The percentage of apoptotic cells after drug exposure was calculated by using the APC Annexin V Apoptosis Detection Kit with Propidium Iodide (PI; BioLegend, San Diego, CA, USA) and following the manufacturer's instructions. Briefly, supernatants were harvested, and the remaining attached cells were trypsinized (Trypsin-EDTA; Corning) and added to the correspondent supernatants. Then, samples were centrifuged for $5 \mathrm{~min}$ at $500 \mathrm{~g}$ at RT, washed with PBS and resuspended in $500 \mu \mathrm{L}$ of Annexin V Binding Buffer (BioLegend), with a maximum concentration of $1 \times 10^{7}$ cells $/ \mathrm{mL}$. Afterwards, $100 \mu \mathrm{L}$ of each sample were passed to a new tube, and $5 \mu \mathrm{L}$ of APC Annexin V (BioLegend) and $10 \mu \mathrm{L}$ of PI (BioLegend) was added. Then, samples were vortexed and incubated for $15 \mathrm{~min}$ at RT, protected from the light. Finally, $400 \mu \mathrm{L}$ of Annexin V Binding Buffer (BioLegend) were added to the samples, before acquisition in a BD LSR Fortessa X-20 (BD Biosciences, San Jose, CA, USA), at Champalimaud Foundation, Lisbon, Portugal. Data were analyzed using FlowJo software (v.10.7.1, for Windows, BD Biosciences), considering double negative staining cells, as living cells, annexin positive cells in early apoptosis and double positive cells (both for annexin and PI) in late apoptosis phase.

\subsection{Animal Population}

The 40 tumor tissue samples used in this study were collected from cats that underwent mastectomy, at the Teaching Hospital of the Faculty of Veterinary Medicine, University of Lisbon, with all the procedures consented by the owners, showing no interference in the animals' well-being. The clinical history of the cats was recorded (Table 4), including breed, age, reproductive status and contraceptive administration, treatment (mastectomy or mastectomy plus chemotherapy), number, location and size of tumor lesions, histopathological classification, ER status, PR status, HER2 status and Ki-67 index, malignancy grade, tumor necrosis, lymphatic invasion, lymphocytic infiltration, cutaneous ulceration, regional lymph node involvement, and clinical stage (TNM system) [2], with tumors being classified into five molecular subtypes [3]. Additionally, the fHER2 was determined as being overexpressed in $33 \%$ of the FMC cases, although her 2 gene amplification was not observed [4]. All samples were frozen at $-80^{\circ} \mathrm{C}$ and stored until further use.

Table 4. Clinicopathological features of female cats with mammary carcinomas enrolled in this study $(n=40)$.

\begin{tabular}{|c|c|c|c|}
\hline Breed & Number (\%) & Age & Number (\%) \\
\hline Indeterminate & $33(82.5 \%)$ & $<8$ years old & $3(7.5 \%)$ \\
\hline Siamese & $4(10 \%)$ & $\geq 8$ years old & $37(92.5 \%)$ \\
\hline Persian & $2(5 \%)$ & \multicolumn{2}{|c|}{ Tumor Size } \\
\hline Norwegian Forest & $1(2.5 \%)$ & $<2 \mathrm{~cm}$ & $9(22.5 \%)$ \\
\hline \multicolumn{2}{|c|}{ Spayed (One Unknown) } & $2-3 \mathrm{~cm}$ & $19(47.5 \%)$ \\
\hline Yes & $19(47.5 \%)$ & $>3 \mathrm{~cm}$ & $12(30 \%)$ \\
\hline No & $20(50 \%)$ & \multicolumn{2}{|c|}{ HP * Classification } \\
\hline \multicolumn{2}{|c|}{ Contraceptives (Seven Unknown) } & $\begin{array}{c}\text { Tubulopapillary } \\
\text { carcinoma }\end{array}$ & $8(20 \%)$ \\
\hline Yes & $23(57.5 \%)$ & Solid carcinoma & $9(22.5 \%)$ \\
\hline No & $10(25 \%)$ & Cribiform carcinoma & $5(12.5 \%)$ \\
\hline \multicolumn{2}{|c|}{ Treatment } & Mucinous carcinoma & $5(12.5 \%)$ \\
\hline Mastectomy & $36(90 \%)$ & Tubular carcinoma & $11(27.5 \%)$ \\
\hline Mastectomy+Chemo & $4(10 \%)$ & $\begin{array}{c}\text { Papillary-cystic } \\
\text { carcinoma }\end{array}$ & $2(5 \%)$ \\
\hline
\end{tabular}


Table 4. Cont.

\begin{tabular}{|c|c|c|c|}
\hline \multicolumn{2}{|c|}{ Multiple Tumors } & \multicolumn{2}{|c|}{ HP * Malignancy Grade } \\
\hline Yes & $31(77.5 \%)$ & $\mathrm{I}$ & $2(5 \%)$ \\
\hline No & $9(22.5 \%)$ & II & $5(12.5 \%)$ \\
\hline \multicolumn{2}{|c|}{$\begin{array}{l}\text { Regional Lymph Node Status (Two } \\
\text { Unknown) }\end{array}$} & III & $33(82.5 \%)$ \\
\hline Positive & $14(35 \%)$ & \multicolumn{2}{|c|}{ Tumor Necrosis } \\
\hline Negative & $24(60 \%)$ & Yes & $29(72.5 \%)$ \\
\hline \multicolumn{2}{|c|}{ Stage (TNM Classification) } & No & $11(27.5 \%)$ \\
\hline I & $9(22.5 \%)$ & \multicolumn{2}{|c|}{ Lymphatic Invasion } \\
\hline II & $7(17.5 \%)$ & Yes & $5(12.5 \%)$ \\
\hline III & $21(52.5 \%)$ & No & $35(87.5 \%)$ \\
\hline IV & $3(7.5 \%)$ & \multicolumn{2}{|c|}{ Lymphocytic Infiltration } \\
\hline \multicolumn{2}{|c|}{ Mammary Location } & Yes & $27(67.5 \%)$ \\
\hline M1 & $11(27.5 \%)$ & No & $13(32.5 \%)$ \\
\hline M2 & $8(20 \%)$ & \multicolumn{2}{|c|}{ Tumor Ulceration } \\
\hline M3 & $14(35 \%)$ & Yes & $3(7.5 \%)$ \\
\hline M4 & $11(27.5 \%)$ & No & $37(92.5 \%)$ \\
\hline \multicolumn{2}{|c|}{ fHER2 Status } & \multicolumn{2}{|c|}{ Ki67 Index } \\
\hline Positive & $12(30 \%)$ & Low $(<14 \%)$ & $30(75 \%)$ \\
\hline Negative & $28(70 \%)$ & High $(\geq 14 \%)$ & $10(25 \%)$ \\
\hline \multicolumn{2}{|c|}{ ER Status } & \multicolumn{2}{|c|}{ PR Status } \\
\hline Positive & $12(30 \%)$ & Positive & $20(50 \%)$ \\
\hline Negative & $28(70 \%)$ & Negative & $20(50 \%)$ \\
\hline
\end{tabular}

\begin{tabular}{cc}
\hline \multicolumn{2}{c}{ Tumor Molecular Subtype } \\
\hline Luminal A & $3(7.5 \%)$ \\
Luminal B & $18(45 \%)$ \\
Luminal & $8(20 \%)$ \\
B/HER2-positive & $4(10 \%)$ \\
HER2-positive & $7(17.5 \%)$ \\
Triple-negative & \\
\hline
\end{tabular}

*HP-histopathological; TNM—tumor, node, metastasis; ER—estrogen receptor; PR—progesterone receptor.

\subsection{DNA Extraction, Amplification and Sequence Analysis of Feline HER2 ECD}

Genomic DNA extraction was performed in $5 \mathrm{mg}$ of 44 frozen tissue samples (4 breed control and 40 tumor tissues) and in the three feline cell lines (CAT-MT, FMCm and FMCp), collected after grown till confluency in a T25 culture flask, as previously described [54,55], using a QIAmp FFPE kit (Qiagen, Dusseldorf, Germany) and following the manufacturer's guidelines. First, tissue samples were homogenized in the Tissue Lyser II (Qiagen), and then, all samples were digested with protease $\mathrm{K}(20 \mathrm{mg} / \mathrm{mL}$; Qiagen). After the washing steps, genomic DNA was eluted from the extraction columns and its quality and quantity was measured in NanoDrop ND-100 Spectrophotometer (Thermo Fischer Scientific). For the amplification of exons 3, 4 and 10-13, which encode for the feline her2 ECD (NC_018736.3), previously identified by comparison with the genomic human her2 sequence (NC_000017.11), different primers were designed (Table 5) in the Primer designing tool (NCBI, Bethesda, MD, USA), and used in a PCR Thermal Cycler (VWR Thermocycler, Leicestershire, England). PCR technique was performed with a standard reaction mixture ( $4 \mu \mathrm{L} /$ sample of Phusion GC buffer (Thermo Fischer Scientific), $0.4 \mu \mathrm{L} /$ sample of dNTPs (Grisp, Porto, Portugal), $0.1 \mu \mathrm{L} /$ sample of each forward and reverse primers and $0.2 \mu \mathrm{L} /$ sample of DNA Polymerase (Thermo Fischer Scientific)), maintaining a final 
DNA concentration of $4 \mathrm{ng} / \mathrm{mL}$. For exons 3, 4, 10 and 11, PCR reactions were performed as follows: denaturation at $98{ }^{\circ} \mathrm{C}$ for $30 \mathrm{~s}$, followed by 35 cycles at $98^{\circ} \mathrm{C}$ for $10 \mathrm{~s}, 58^{\circ} \mathrm{C}$ for $30 \mathrm{~s}, 72{ }^{\circ} \mathrm{C}$ for $10 \mathrm{~s}$, plus one final extension step at $72{ }^{\circ} \mathrm{C}$ for $10 \mathrm{~min}$. For exons 12 and 13 a nested-PCR was performed, using two pairs of primers, initially with a melting temperature of $55{ }^{\circ} \mathrm{C}$, followed by a melting temperature of $52{ }^{\circ} \mathrm{C}$ for the second pair of primers. After confirmation of the expected size for each amplified sequence in a $2 \%$ agarose gel (Sigma-Aldrich), DNA fragments were purified and sequenced by Sanger technique (StabVida, Almada, Portugal), and checked for inaccuracies.

Table 5. Primers for genomic DNA amplification and sequencing of exons 3, 4 and 10-13 of the feline her2 ECD.

\begin{tabular}{|c|c|c|}
\hline Exons & Forward $\left(5^{\prime}-3^{\prime}\right)$ & Reverse $\left(5^{\prime}-3^{\prime}\right)$ \\
\hline 3 & GGCGCTTGCTCATAGTTCAC & ATCAAACTGTGCAGGCTCGT \\
\hline 4 & GAGGCCTGCTCСССТСТАAA & AAGAGGGAATGGGTAGCGTT \\
\hline $10-11$ & GGGCTTGGGCTTTGAAACTC & TGAAGGGTCAGCGAGTAAGC \\
\hline 12-13(1st pair) & TGGGAGTTTTCGGAGTGTGC & AAGCCTGACAGAAGGGATGG \\
\hline 12-13 (2nd pair) & GTGCTTACTCGCTGACCCTTCA & ACCCCTGCAATACTCGGCATTC \\
\hline
\end{tabular}

The feline sequenced samples were aligned with the identified feline her2 (NC_018736.3), using the ClustalW tool (BioEdit Alignment Editor software) [56], while the consensus sequence was confirmed using the SeqTrace 9.1 software [57]. Protein mutations and SNP loci were identified using the Expert Protein Analysis System (ExPASY) translate tool and compared with the original protein sequence (NP_001041628.1, NCBI). Mutations identified in the feline tissue samples were compared to the human her2 sequence (NC_000017.11) and searched in National Cancer Institute, International Cancer Genome Consortium and Catalogue of Somatic Mutations in Cancer (COSMIC) databases for putatively induced resistance to $\mathrm{mAbs}$, and the ADC tested in this study.

\subsection{Statistical Analysis}

Statistical analysis was carried out using the GraphPad Prism software (version 5.04, for Windows, San Diego, CA, USA), with two-tailed $p$-values below 0.05 being considered statistically significant, and a 95\% confidence interval $\left({ }^{*} p<0.05,{ }^{* *} p<0.01\right.$ and $\left.{ }^{* * *} p<0.001\right)$. For the cytotoxicity assays, outliers with more than two standard deviations were removed from the analysis and the $\mathrm{EC}_{50}$ value for each drug, in all the cell lines was calculated using Log (agonist) vs. Response (Variable slope) function. In the drug conjugation assays, the two-way ANOVA test was performed. Regarding the mutations found in tissue samples, associations between groups were assessed using the nonparametric Fisher's exact test.

\section{Results}

\subsection{Trastuzumab, Pertuzumab and T-DM1 Presented Antiproliferative Effects in FMC Cell Lines}

Trastuzumab, pertuzumab and T-DM1 exhibited a dose-dependent antiproliferative effect on feline mammary carcinoma cell lines. Indeed, trastuzumab exerted a more potent antiproliferative effect on CAT-MT cell line $\left(92.6 \%\right.$ of cytotoxicity, $\mathrm{EC}_{50}=3047.89 \mu \mathrm{g} / \mathrm{mL} \pm 1.43$; Figure 1A) in comparison with the effects on the $\mathrm{FMCm}(82.7 \%$ of cytotoxicity, $\left.\mathrm{EC}_{50}=528.45 \mu \mathrm{g} / \mathrm{mL} \pm 1.14\right)$ and FMCp $\left(60.1 \%\right.$ of cytotoxicity, $\left.\mathrm{EC}_{50}=3243.40 \mu \mathrm{g} / \mathrm{mL} \pm 2.29\right)$ cell lines. In parallel, pertuzumab showed similar results on CAT-MT and FMCm cell lines $\left(60.2 \%\right.$ and $61.8 \%$ of cytotoxicity, $\mathrm{EC}_{50}=2837.92 \mu \mathrm{g} / \mathrm{mL} \pm 1.50$ and $\mathrm{EC}_{50}=1205.04 \mu \mathrm{g} / \mathrm{mL}$ \pm 1.23 , respectively; Figure 1B), with the feline HER2-negative cell line, FMCp presenting the lowest antiproliferative effect $\left(52.1 \%\right.$ of cytotoxicity, $\left.\mathrm{EC}_{50}=928.97 \mu \mathrm{g} / \mathrm{mL} \pm 1.11\right)$. Regarding the ADC T-DM1, the highest antiproliferative effect, at the range of concentrations tested, was reported on CAT-MT and FMCp cells $(94.0 \%$ and $74.2 \%$ of cytotoxicity, $\mathrm{EC}_{50}=19.63 \mu \mathrm{g} / \mathrm{mL} \pm 1.22$ and $\mathrm{EC}_{50}=88.72 \mu \mathrm{g} / \mathrm{mL} \pm 1.29$, respectively; Figure 1C), with similar cytotoxicity being detected on FMCm and SKBR-3 cell lines $(53.8 \%$ and $50.5 \%$ of cytotoxicity, respectively; $\left.\mathrm{EC}_{50}(\mathrm{FMCm})=52.84 \mu \mathrm{g} / \mathrm{mL} \pm 1.50\right)$. 

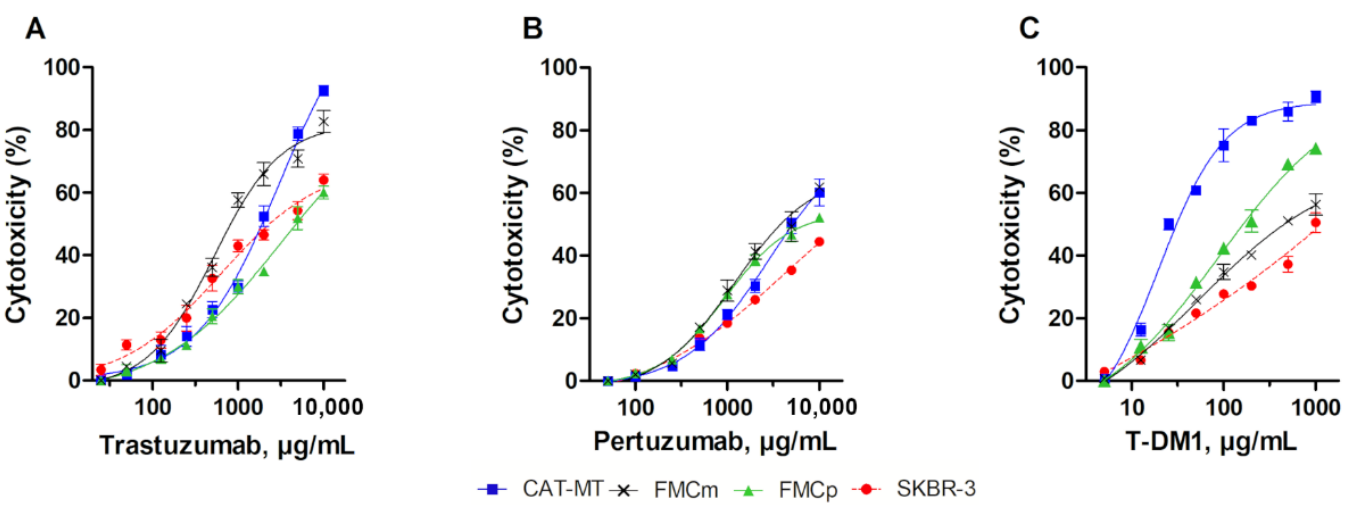

Figure 1. Trastuzumab, pertuzumab and T-DM1 presented strong antiproliferative effects on feline mammary carcinoma cell lines. (A) CAT-MT cells exposure to trastuzumab allowed to obtain a maximum of $92.6 \%$ of cytotoxicity. (B) Cell lines exposure to pertuzumab presented a lower antiproliferative effect, with a maximum of $61.8 \%$ of cytotoxicity in the FMCm cells. (C) T-DM1 had the highest antiproliferative effect in the CAT-MT cells, with $94.0 \%$ of cytotoxicity. The experiments were performed in triplicates, in three independent assays.

In order to interpret the response of cell lines to anti-HER2 agents, the HER2 expression status was determined. Interestingly, all feline cell lines showed lower HER2 scores than the human SKBR-3 cell line (scored as 3+, Figure 2D), with CAT-MT cells showing a 2+ score (Figure 2A), FMCm cells showing 1+ HER-2 positivity (Figure 2B) and FMCp cells showing no immunostaining signal (0 score, Figure $2 \mathrm{C}$ ).

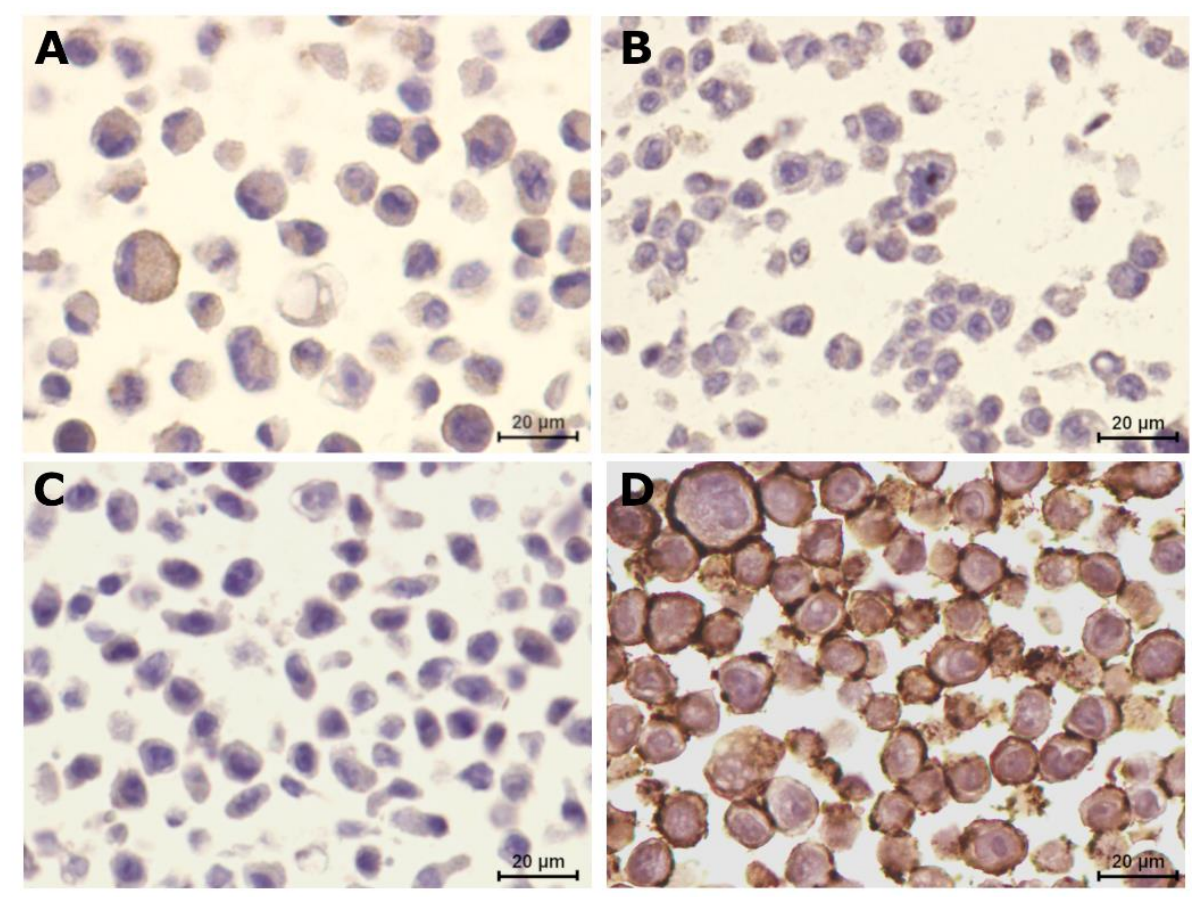

Figure 2. Feline mammary carcinoma cell lines presented different HER2 expressions. (A) CAT-MT cell line was classified as HER2-positive (HER2 2+ score). (B) FMCm was classified with 1+ score, being considered slightly positive for HER2 expression. (C) FMCp cell line presented no HER2 signal (HER2-negative). (D) The human SKBR-3 cell line was classified as a HER2-overexpressing cell line (3+ score). $400 \times$ magnification.

\subsection{Apoptosis Is the Main Mechanism of Cell Death Caused by Anti-HER2 mAbs and $A D C$ T-DM1}

Flow cytometry analysis of feline cell lines exposed to anti-HER2 mAbs (trastuzumab and pertuzumab) or ADC (T-DM1) allowed to confirm that the observed antiproliferative 
effects were related to apoptosis induction (Figure 3). Deepening the analysis, we observed that the HER2-overexpressing CAT-MT cell line showed the higher percentage of cells in late apoptosis for both $\mathrm{mAbs}$, reaching a maximum of $53.1 \% \pm 2.54$ of apoptotic cells after trastuzumab exposure (14.1\% early apoptosis and $39.0 \%$ late apoptosis) and $65.3 \% \pm 2.33$ after treated with pertuzumab (12.8\% early apoptosis and $52.5 \%$ late apoptosis; Figure $3 \mathrm{~A})$. The balance between early and late apoptosis was similar when cells were treated with T-DM1 $(41.7 \%$ and $39.6 \%$, respectively), with a maximum of $81.3 \% \pm 1.61$ of apoptotic cells. In FMCm cell line the percentage of cells in late apoptosis was the highest, presenting $52 \% \pm 4.02$ of apoptotic cells ( $10.5 \%$ early apoptosis and $41.5 \%$ late apoptosis) after exposure to trastuzumab, $44.4 \% \pm 1.04$ as response to pertuzumab (12.1\% early apoptosis and $32.3 \%$ late apoptosis) and $74.2 \% \pm 6.06$ of apoptotic cells ( $25.1 \%$ early apoptosis and $49.1 \%$ late apoptosis) after T-DM1 incubation (Figure 3B). A different behavior was observed in the FMCp cell line that showed a higher percentage of cells in early apoptosis. The total percentage of apoptotic cells after exposure to trastuzumab was $44.5 \% \pm 1.64(36.4 \%$ early apoptosis and $8.1 \%$ late apoptosis), and $52.3 \% \pm 1.79$ (47.1\% early apoptosis and $5.2 \%$ late apoptosis) after pertuzumab exposure. In these cells, T-DM1 induced $44.5 \% \pm 2.63$ of cellular apoptosis (41.9\% early apoptosis and 2.6\% late apoptosis; Figure 3C). Lastly, the human SKBR-3 cells used as control, showed expected results, with an average of $48.8 \% \pm 1.62$ of apoptotic cells when exposed to trastuzumab and pertuzumab, similarly distributed between early and late apoptosis stages (average $22.2 \%$ and $26.6 \%$, respectively), with the percentage of apoptotic cells being higher after T-DM1 exposure $(80.1 \% \pm 2.00 ; 27.5 \%$ early apoptosis and 52.6\% late apoptosis; Figure 3D).

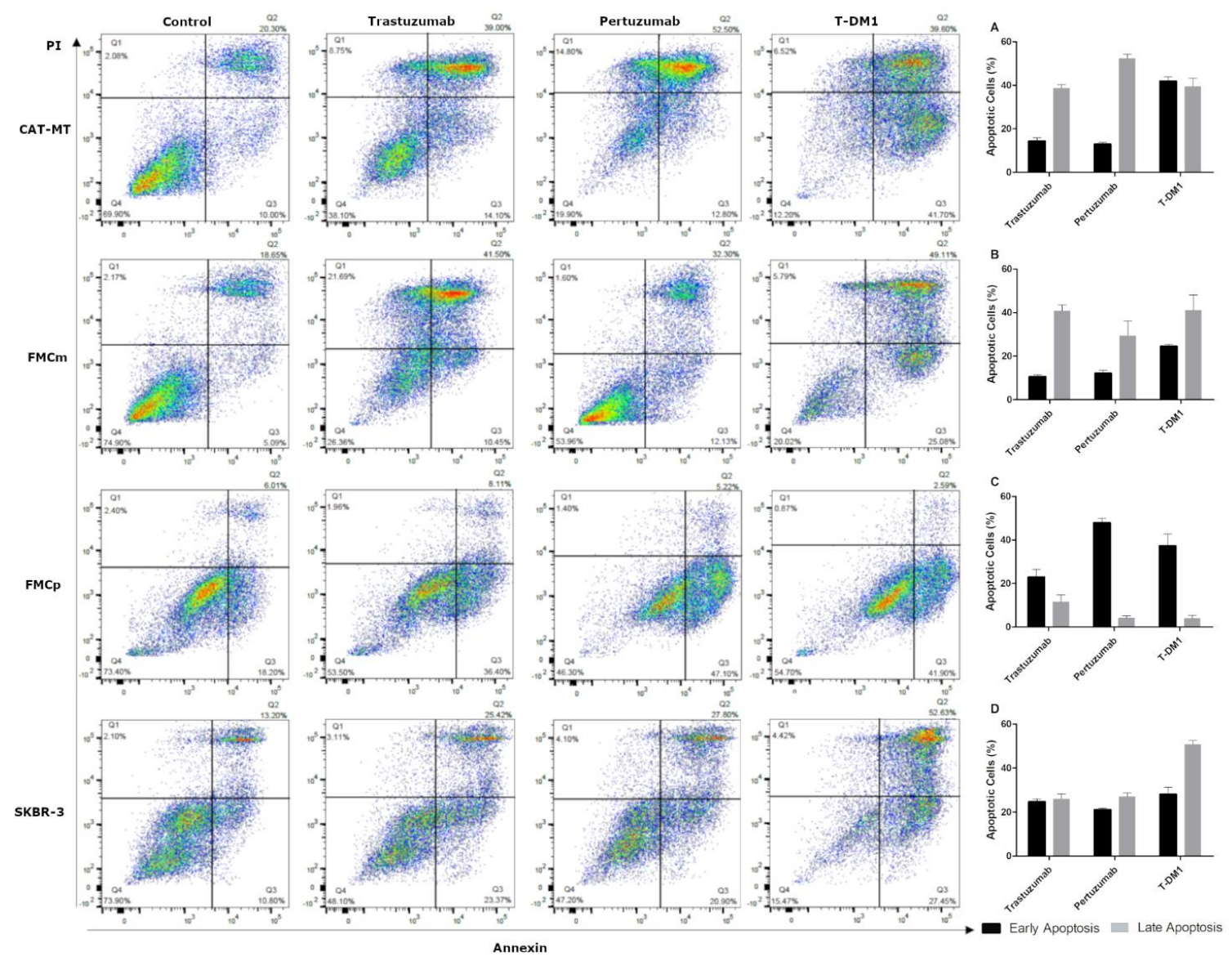

Figure 3. Trastuzumab, pertuzumab and T-DM1 induce apoptosis in the feline cell lines. (A) CAT-MT and (B) FMCm cell lines presented an increase in cell apoptosis after drugs exposure, being the cells predominantly in late apoptosis phase. (C) In the FMCp cell line, cells occurred predominantly in early stage apoptosis. (D) The human SKBR-3 cell line had an equilibrated death pattern, between early and late stage apoptosis, with the cells mainly in late apoptosis phase, by exposure to T-DM1. The experiment was performed in triplicates and repeated simultaneously three times. 
3.3. Combined Exposures of Two Anti-HER2 mAbs and Anti-HER2 mAbs with Lapatinib Showed Synergistic Antiproliferative Effects

The combination trastuzumab plus pertuzumab showed synergistic antiproliferative effects in all feline cell lines. In CAT-MT cells the exposure to trastuzumab at $125 \mu \mathrm{g} / \mathrm{mL}$ plus pertuzumab at $2000 \mu \mathrm{g} / \mathrm{mL}$ increased the cytotoxicity from $13.6 \%$ to $40.0 \%(p<0.001$; Figure $4 \mathrm{~A}$ ). For the FMCm cells, the cytotoxic effect was increased from $15.6 \%$ to $45.1 \%$ $(p<0.001$; Figure 4B), after exposure to trastuzumab at $125 \mu \mathrm{g} / \mathrm{mL}$ plus pertuzumab at $2000 \mu \mathrm{g} / \mathrm{mL}$. Finally, in the FMCp cell line, the highest antiproliferative effect was obtained using trastuzumab at $500 \mu \mathrm{g} / \mathrm{mL}$ plus pertuzumab at $2000 \mu \mathrm{g} / \mathrm{mL}$, increasing the cytotoxicity from $17.1 \%$ to $28.8 \%$ ( $p=0.018$; Figure 4 C). In the human SKBR-3 cells, all the conjugations tested exerted a significant increase of the antiproliferative effect $(p<0.001$; Figure 4D).
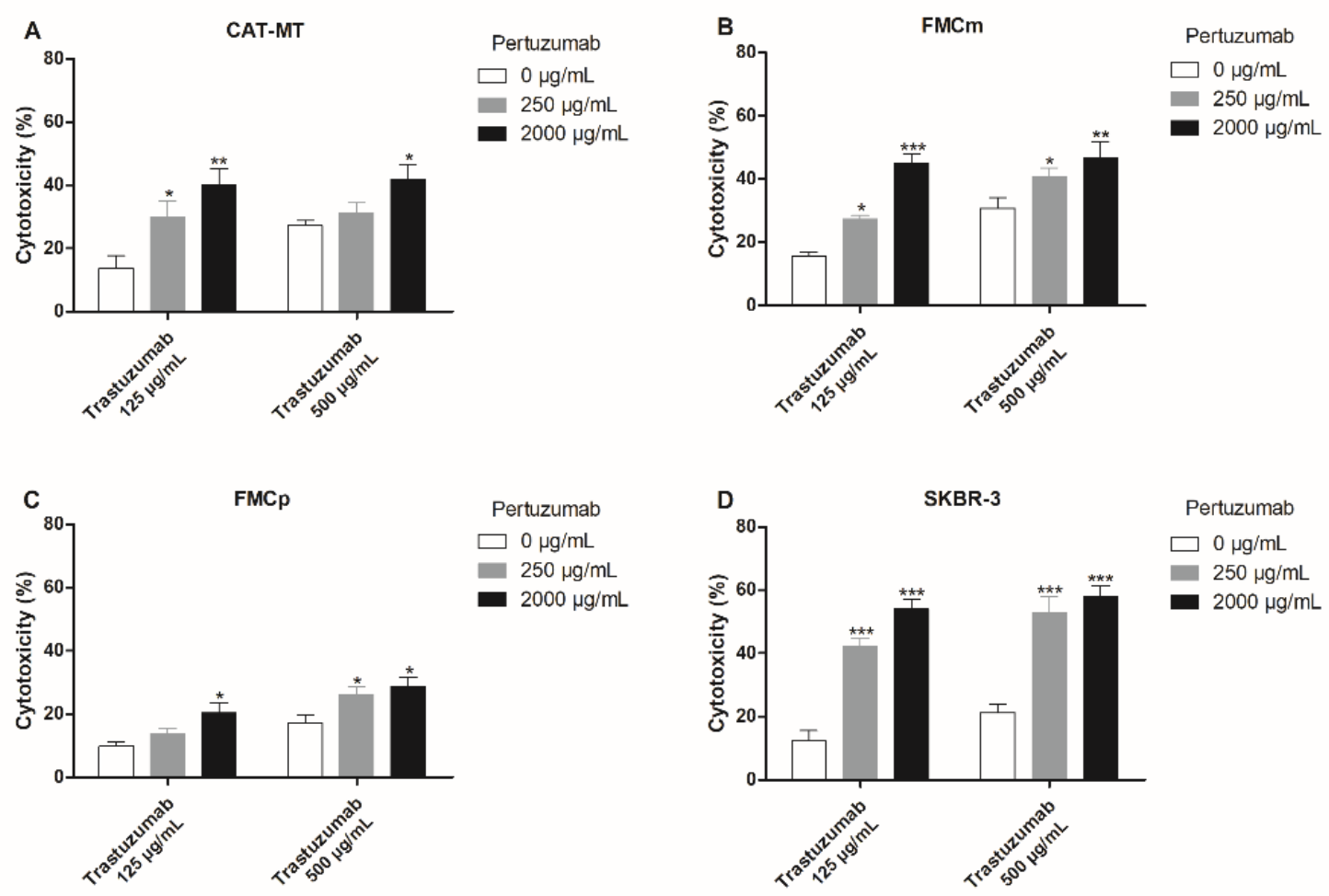

Figure 4. Combined treatments with trastuzumab plus pertuzumab showed synergistic antiproliferative effects in the carcinoma cell lines. (A) CAT-MT cells presented the highest cytotoxic response by the use of trastuzumab at $125 \mu \mathrm{g} / \mathrm{mL}$ plus pertuzumab at $2000 \mu \mathrm{g} / \mathrm{mL}$, being possible to achieve $40.0 \%$ of cytotoxicity $(* * p<0.01)$. (B) In FMCm cell line, the combination trastuzumab at $125 \mu \mathrm{g} / \mathrm{mL}$ plus pertuzumab at $2000 \mu \mathrm{g} / \mathrm{mL}$ was the one that allows to achieve the highest cytotoxic effect, $45.1 \%$ of cytotoxicity $\left({ }^{* *} p<0.001\right)$. (C) In the FMCp cells a maximum cytotoxic effect of $28.8 \%$ using the combination trastuzumab at $500 \mu \mathrm{g} / \mathrm{mL}$ plus pertuzumab at $2000 \mu \mathrm{g} / \mathrm{mL}\left({ }^{*} p<0.05\right.$ ) was achieved. (D) Similarly to the feline cell lines, in the human SKBR-3 cell line synergistic antiproliferative effects were obtained, revealing all the combinations valuable. The experiments were performed in triplicates and repeated three separate times.

The use of the anti-HER2 mAbs (trastuzumab and pertuzumab) combined with lapatinib showed an improvement of the antiproliferative effects induced by mAbs. Accordingly, the combination of trastuzumab plus lapatinib, in the CAT-MT cell line, revealed a valuable synergistic response, for all the concentrations tested, with the highest increase of $78.4 \%$ of cytotoxicity, by the combination of trastuzumab at $125 \mu \mathrm{g} / \mathrm{mL}$ plus lapatinib at $7.26 \mu \mathrm{g} / \mathrm{mL}$ $(p<0.001$; Figure 5A). The other two feline cell lines (FMCm and FMCp) presented different behaviors. While, the FMCm cells presented a lower response, with the highest antiproliferative effect occurring by exposure to trastuzumab at $125 \mu \mathrm{g} / \mathrm{mL}$ plus lapatinib at $7.26 \mu \mathrm{g} / \mathrm{mL}$, increasing the cytotoxicity from $10.2 \%$ to $37.4 \%$ ( $p=0.0017$; Figure $5 \mathrm{~B})$, the FMCp 
cells had a significant decrease in its proliferation rate for all the combinations tested $(p<0.001$; Figure 5C), with a maximum cytotoxic effect of $84.6 \%$ of cytotoxicity, by combining trastuzumab at $500 \mu \mathrm{g} / \mathrm{mL}$ plus lapatinib at $7.26 \mu \mathrm{g} / \mathrm{mL}$. In the SKBR-3 cell line all the concentrations tested presented an effective synergistic response ( $p<0.001$; Figure 5D).
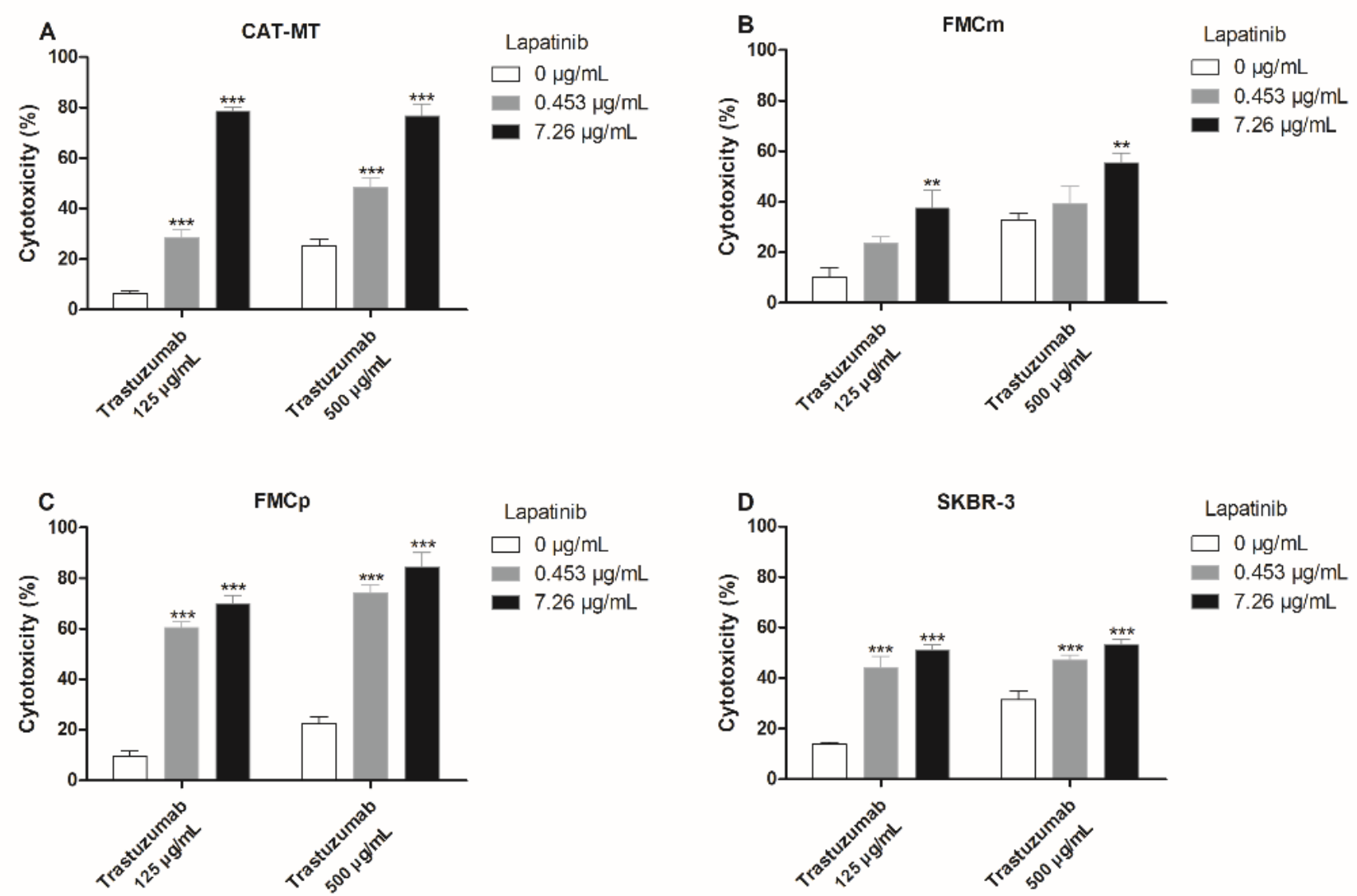

Figure 5. Combined treatments with trastuzumab plus lapatinib allowed to obtain a valuable synergistic antiproliferative effect in the carcinoma cell lines. (A) CAT-MT and (C) FMCp cells presented a significant increase in the cytotoxicity for all the concentrations tested (*** $p<0.001$ ). (B) FMCm cells presented the highest increase in the cytotoxic effect by the combination trastuzumab at $125 \mu \mathrm{g} / \mathrm{mL}$ plus lapatinib at $7.26 \mu \mathrm{g} / \mathrm{mL}$, being possible to achieve $37.4 \%$ of cytotoxicity $\left.{ }^{* *} p<0.01\right)$. (D) In the human SKBR-3 cell line, all the combinations presented a synergistic antiproliferative effect $\left.{ }^{* * *} p<0.001\right)$. The experiments were performed in triplicates and repeated three separated times.

Similarly to the previous results, the combination of pertuzumab plus lapatinib also revealed to be valuable, increasing the $\mathrm{mAb}$ 's antiproliferative effects. In fact, the combination of pertuzumab at $250 \mu \mathrm{g} / \mathrm{mL}$ plus lapatinib at $7.26 \mu \mathrm{g} / \mathrm{mL}$, in the CAT-MT cells revealed a synergistic effect, with an increase from $7.4 \%$ to $76.8 \%$ of cytotoxicity $(p<0.001$; Figure 6A). Again, the FMCm cell line presented to be the less sensitive, a maximum antiproliferative effect being obtained by exposure to pertuzumab at $250 \mu \mathrm{g} / \mathrm{mL}$ plus lapatinib at $7.26 \mu \mathrm{g} / \mathrm{mL}$, increasing the cytotoxicity from $6.3 \%$ to $47.8 \%(p<0.001$; Figure $6 \mathrm{~B})$. In the FMCp cells the highest increase in the cytotoxic effect was observed using pertuzumab at $250 \mu \mathrm{g} / \mathrm{mL}$ plus lapatinib at $7.26 \mu \mathrm{g} / \mathrm{mL}$, increasing the cytotoxicity from $6.2 \%$ to $53.7 \%$ $(p<0.001$; Figure 6C). As control, the human cell line SKBR-3 also presented an effective increase in the antiproliferative effects of the combined assays ( $p<0.001$; Figure $6 \mathrm{D})$, for all the concentrations tested. 

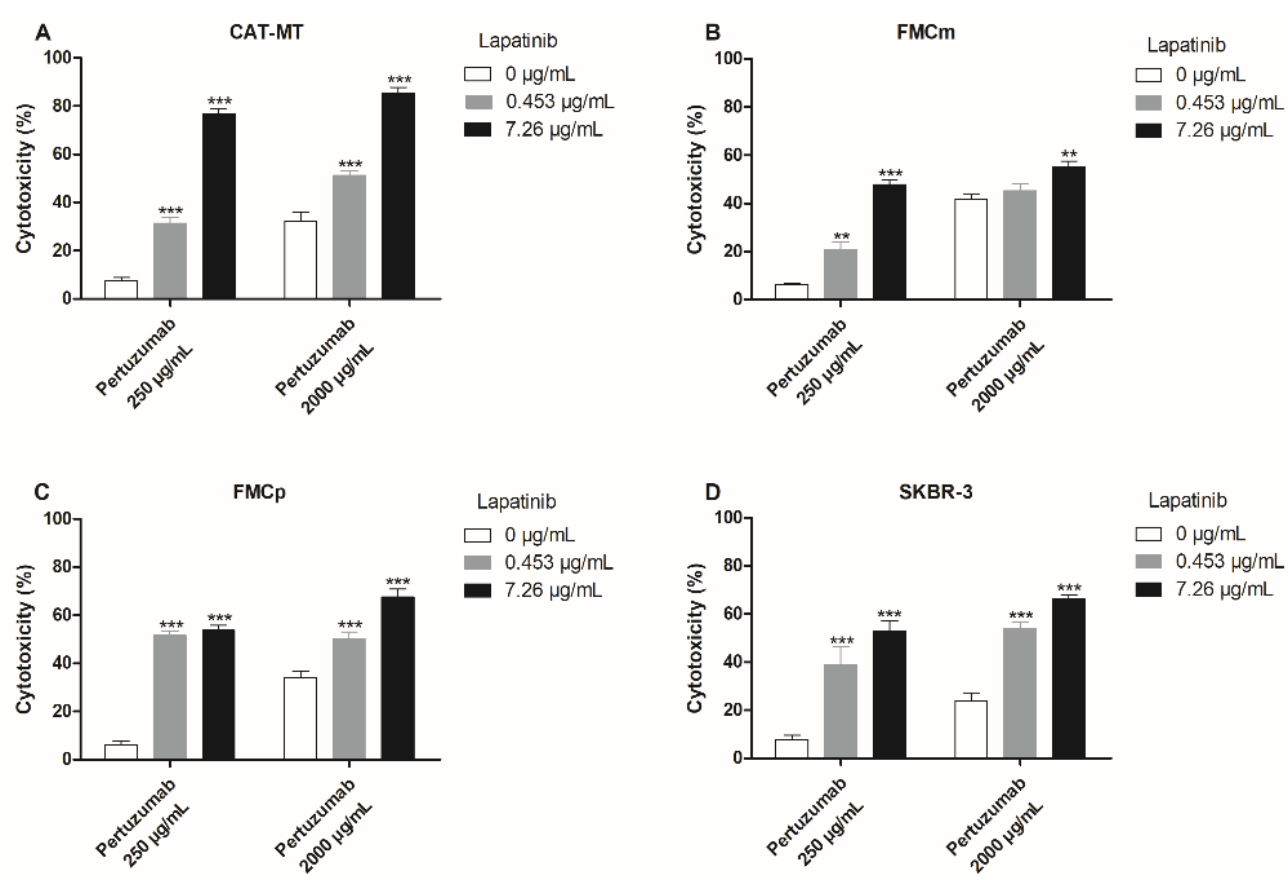

Figure 6. The combination of pertuzumab with lapatinib showed an improved antiproliferative effect in all the carcinoma cell lines. (A) CAT-MT cells presented synergistic antiproliferative effects for all the conjugations tested, the highest cytotoxic response occurring by the use of pertuzumab at $250 \mu \mathrm{g} / \mathrm{mL}$ plus lapatinib at $7.26 \mu \mathrm{g} / \mathrm{mL}$, with $76.8 \%$ of cytotoxicity (*** $p<0.001$ ). (B) The FMCm cells achieved the highest synergist effect, by the use of pertuzumab at $250 \mu \mathrm{g} / \mathrm{mL}$ plus lapatinib at $7.26 \mu \mathrm{g} / \mathrm{mL}$, with $47.8 \%$ of cytotoxicity $(* * * p<001$ ), while the combination of pertuzumab at $2000 \mu \mathrm{g} / \mathrm{mL}$ plus lapatinib at $7.26 \mu \mathrm{g} / \mathrm{mL}$ presented a smaller cytotoxic effect $\left({ }^{* *} p<0.01\right)$. (C) The combination of pertuzumab at $250 \mu \mathrm{g} / \mathrm{mL}$ plus lapatinib at $7.26 \mu \mathrm{g} / \mathrm{mL}$, in the FMCp cells, allowed to obtain $53.7 \%$ of cytotoxicity $(* * *<<0.001)$. (D) As control, the human SKBR-3 cell line presented a synergistic effect for all the conjugations tested $(* * p<0.001)$. The experiments were performed in triplicates and repeated three separated times.

3.4. In the FMC Clinical Samples, Mutations Found in the HER2 ECD, Subdomains II and IV Were Not Associated with Immunotherapy Resistance in Humans

Previous studies on somatic mutations in the her 2 gene, in human breast cancer patients, revealed several mutations associated with resistance to therapy and/or specific clinicopathological features, reported in National Cancer Institute, International Cancer Genome Consortium and COSMIC databases. In this work, the FMC clinical samples revealed that $45 \%(18 / 40)$ presented at least one mutation (Figure 7; Table S2), with all of them showing a low frequency $(\mathrm{n}=1)$, and the majority being homozygous $(83.3 \% ; 30 / 36$ mutations). Detected mutations were more frequent in luminal B tumors $(61.1 \% ; 11 / 18)$, followed by the luminal B/HER2-positive subtype (50\%; 4/8) and triple-negative tumor samples $(42.9 \% ; 3 / 7)$, with no mutations identified in HER2-positive $(\mathrm{n}=4)$ and luminal A $(n=3)$ tumor subtypes. Further analysis revealed that in the region recognized by pertuzumab, her2 subdomain II, while $69.4 \%$ (25/36 mutations) of the mutations were located in exon 3 (11/40 tumor samples), no mutations were found in the exon 4. Additionally, exon 3 presented 11 synonymous and 10 missense mutations, the remaining four being silent mutations. Regarding the subdomain IV, which is the her 2 region recognized by trastuzumab, few mutations were detected, namely one heterozygous missense mutation at exon $10(2.8 \% ; 1 / 36)$, in two tumor samples; five mutations in exon $11(13.9 \%$; 5/36 mutations), one being a heterozygous synonymous mutation and four missense mutations, occurring in three tumor samples; two mutations at exon 12 (5.6\%; 2/36 mutations), occurring in two tumor samples, one of them synonymous; three mutations at exon 13 (8.3\%; $3 / 36$ mutations), in two tumor samples, one synonymous, one missense and one frameshift mutation (c.14406 Ins. C). 


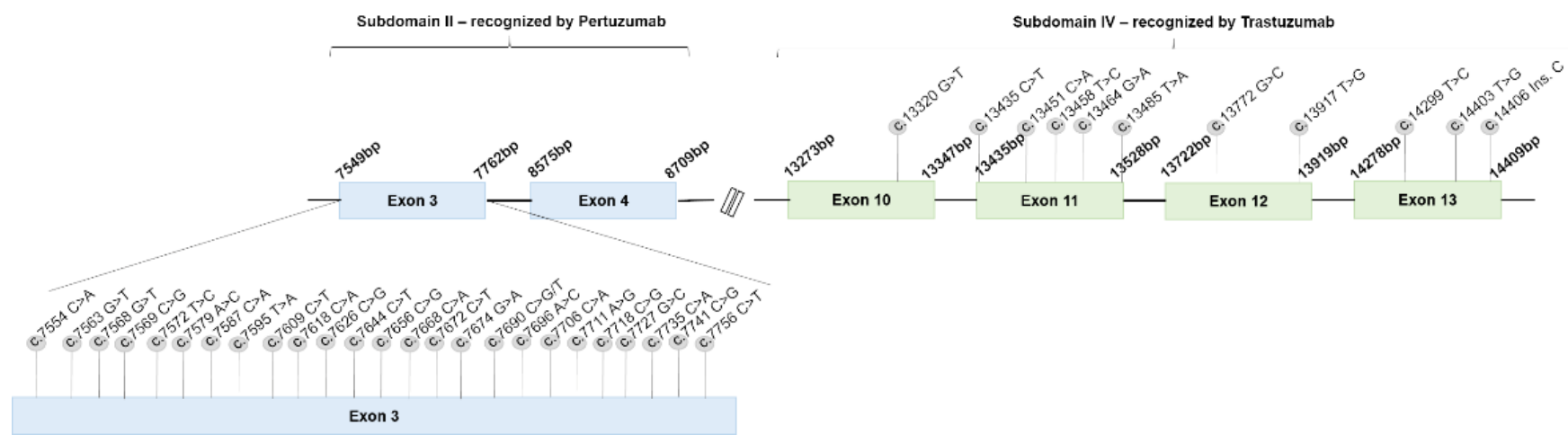

Figure 7. Mutations identified in the feline her2 ECD, subdomains II and IV were not reported as induce resistance to therapy. All the mutations found occur in a low frequency $(n=1)$, being more common in exon 3, subdomain II $(69.4 \%)$. Any of the described mutations were reported in breast cancer patients as induce therapeutic resistance.

Additionally, any correlation was reported between animals' clinicopathological features and the described mutations. Moreover, after comparing the feline mutations with the genomic human her $2 \mathrm{ECD}$ sequence, and searching in the referred databases, the mutations found were never reported as inducing resistance to anti-HER2 immunotherapy in breast cancer patients.

\section{Discussion}

The FMC is a common disease, showing similar features with human breast cancer $[1,2]$. Presently, a lack of therapeutic options combined with a late diagnosis have a severe impact on overall survival and disease-free survival of cats with mammary carcinoma. Thus, to overcome this problem, and since the cat is a good cancer model [58], the antiproliferative effects of two anti-HER2 mAbs (trastuzumab and pertuzumab) and one ADC (T-DM1) were evaluated, using a FMC cell-based model (CAT-MT, FMCm and FMCp cell lines), presenting different HER2 expression levels, and with no mutations described as conducing to resistance to therapy (Table S3).

Currently, only one felinized $\mathrm{mAb}$ is known to be in use as a therapeutic option for cats $[59,60]$, with no information about the use of mAbs in the treatment of the FMC. Furthermore, despite the reproducible $[61,62]$ and promising results obtained by testing human $\mathrm{TKi}$, approved for breast cancer patients (lapatinib and neratinib), in FMC cell-based models, achieving $100 \%$ of cytotoxicity by the use of lapatinib (average $\mathrm{IC}_{50}=8756 \mathrm{nM} \pm 83$ ), and a maximum of $79.4 \%$ of cytotoxicity in the FMCp cell line, by exposure to neratinib [63], no clinical trials are performed. In cats, the approved TKi are not specific for the mammary tumors, and are associated with severe side effects [64]. Thus, the immunotherapy protocols, using mAbs could arise has an alternative to chemotherapy. Accordingly, trastuzumab avoids HER2 homodimerization and its ECD shedding, leading to HER2 endocytic destruction. Furthermore, this mAb promotes an immune activation [20], inducing apoptosis, by the reduction of the antiapoptotic Mcl-1 protein expression [65], and the inhibition of PI3K/AKT [66], a crucial cell survival pathway [5]. This study demonstrated that trastuzumab presented similar effects between the feline and human cell lines [67,68], being possible to report a maximum of $92.6 \%$ of cytotoxicity for the CAT-MT cells and $82.7 \%$ of cytotoxicity for the FMCm cells, both HER2-positive. Particularly, for the FMCm cell line it was demonstrated that the HER2 expression levels are an upstream activator of the AKT pathway [5], demonstrating this $\mathrm{mAb}$ an important effect, by blocking the HER2 protein and contradicting this cycle. On the other hand, for the HER2-negative FMCp cell line, the cytotoxic effect obtained was the lowest (60.1\% of cytotoxicity), suggesting that the lack of HER2 receptor [69] decreases trastuzumab efficacy. Additionally, such as described in other studies, the HER2 expression in the FMCp cell line is not completely null $[5,51]$. This result could be associated to the expression of an activated HER2 (Y877) protein, already described in triple-negative human tumors, being responsible for the 
benefits of trastuzumab in some breast tumor patients [70]. Furthermore, similar results between cell lines were obtained by the use of pertuzumab, as reported in other studies [68,71,72]. Pertuzumab inhibits heregulin induced heterodimerization HER2-HER3 [73], with a decrease in the activation of the PI3K [74] and ERK pathways [75]. Analyzing this assay, it was possible to obtain $60.2 \%$ and $61.8 \%$ of cytotoxicity, for CAT-MT and the metastatic FMCm cell lines, respectively. Interestingly, similarly to the trastuzumab effect, FMCp cells exposed to pertuzumab, revealed a good cytotoxic response $(52.1 \%$ of cytotoxicity). In fact, pertuzumab was suggested for the treatment of triple-negative human breast cancer, which express the circular HER2 RNA, encoding for HER2-103, as putatively occurring with the FMCp cell line [51], which is antagonized by pertuzumab [76]. Finally, ADC T-DM1 allows a selective delivery of the DM-1 molecule to the HER2-expressing tumor cells, preventing the HER2 homodimerization, and inhibiting the microtubule assembly [77], which induces cell apoptosis [39,40,77], by blocking the AKT/mTOR pathway [40]. In the experimental assay, T-DM1 was tested in lower concentrations, comparing to mAbs, and showing superior cytotoxic effects, directly dependent on the cell membrane HER2 concentration [39]. In fact, $94.0 \%$ of cytotoxicity was obtained for the CAT-MT cells, presenting a HER 2 2+ score, and $53.8 \%$ of cytotoxicity for the metastatic FMCm cells, with a HER2 1+ score. Interestingly, the cytotoxic effect of T-DM1 in the FMCp cell line presented promising results, $74.2 \%$ of cytotoxicity being obtained, which could be explained by the axis DM-1/cytoskeleton-associated protein 5 (CKAP5) a microtubule regulator protein, cell surface target for T-DM1, inducing cytotoxicity in no HER2-overexpressing cells [78], suggested as a target in triple-negative breast cancer therapy [79]. Furthermore, we were unsuccessful in reproducing the cytotoxic effect in the SKBR-3 cell line after T-DM1 exposure $[42,78,80]$, obtaining $50.5 \%$ of cytotoxicity, at the maximum concentration tested $(1000 \mu \mathrm{g} / \mathrm{mL})$. Although the general characteristics of the tumor are maintained (Figure S1 and Table S1), this result could be explained due to molecular changes along cell culture $[81,82]$. Unfortunately, it was not possible to achieve $100 \%$ of cytotoxicity, with any of the compounds tested, which could be explained due to a need of a 3D system, allowing a proper antigen-antibody conformational interaction [71,83].

The tested mAbs and the ADC cell death mechanism occur by apoptosis, suggesting a Bcl-2 dependent mechanism [84], conserved between the feline and human cell lines $[33,39,65]$. Furthermore, the majority of the cells occurred in late phase apoptosis after drug exposure, presenting a permeabilized cell membrane [85] (Annexin positive vs. PI positive). Nevertheless, in the FMCp cell line a higher percentage of cells occur in early phase apoptosis (Annexin positive vs. PI negative), for all the compounds tested, suggesting the need of a more prolonged exposure time to achieve the late phase apoptosis.

As for human breast cancer, combined protocols reveal to be a valuable tool $[44,86,87]$ in the feline mammary tumor cell lines, presenting antiproliferative synergistic effects, by the use of smaller drug concentrations, and preventing the acquired resistance to therapy, known for trastuzumab [88-93], as well as for pertuzumab [94]. In the conjugation trastuzumab plus pertuzumab the obtained response was known by block heterodimers formation, canceling the influence of HER2-overexpression on cell cycle and blocking the signaling through AKT [45]. This combination reveals to be valuable for all the feline cell lines, with the highest increase in cytotoxicity in the FMCm cell line (from 15.6\% to $45.1 \%$ of cytotoxicity). Better results were obtained, considering the conjugations of $\mathrm{mAbs}$ plus the TKi, lapatinib, already approved for combined protocols in human breast cancer [95-97], and revealing valuable in FMC cell-based models [63]. In the combined treatments similar results to the SKBR-3 cell line [47] were obtained, revealing for all the combinations a synergistic behavior. The best conjugation reveals to be trastuzumab plus lapatinib, with a highest increase of $71.9 \%$ of cytotoxicity (from $6.52 \%$ to $78.4 \%$ of cytotoxicity), in the CAT-MT cell line. This combination is valuable since the TKi enhances trastuzumab mediated ADCC, by upregulating the HER2 expression [97]. Nevertheless, the conjugation pertuzumab plus lapatinib also presented a good improvement of the antiproliferative effects, with the highest increase of $69.4 \%$ of cytotoxicity (from $7.4 \%$ to 
$76.8 \%$ of cytotoxicity), also occurring in the CAT-MT cell line. In this study we associated $\mathrm{mAbs}$ with the reversible TKi, lapatinib, but combined protocols of $\mathrm{mAbs}$ with the irreversible TKi, neratinib, have been revealing valuable tools for the treatment of breast cancer patients [98]. Furthermore, considering the promising results obtained by the use of neratinb, in the FMC cell lines [63], more studies are needed with neratinib in conjugation assays, to unveil different possibilities for the treatment of cats with mammary carcinomas.

Beyond the acquired therapy resistance, somatic mutations in the her 2 ECD could explain the resistance patterns obtained with the use of anti-HER2 molecules, although mutations in the her2 gene are described as more common in the TK domain [35], and in triple-negative tumor subtype [99]. In the FMC clinical samples, mutations revealed to occur with higher frequency in the luminal B subtype (61.1\%). In the studied population, the majority of the her 2 ECD mutations occurred in exon $3(69.4 \%)$, subdomain II, which encode for the region recognized by pertuzumab, suggesting that if resistance occurs in cat, it might be more common in therapeutic protocols using this mAb. Additionally, $38.9 \%$ (14/36 mutations) of the mutations were synonymous and $61.1 \%$ (22/36 mutations) corresponds to missense mutations, conditioning $59.1 \%$ (13/22 mutations) of them a change in the polarity of the codified codon, which could modify the 3D arrangement of the protein [100]. In breast cancer patients, one of the most described mutations in the her $2 \mathrm{ECD}$ is $\mathrm{S} 310 \mathrm{~F} / \mathrm{Y}$, related to a resistant pattern to trastuzumab [101] and pertuzumab [35,102] therapies, not reported in our population. Furthermore, none of the mutations found in the her2 ECD were described as inducing resistance to therapy, according to National Cancer Institute, International Cancer Genome Consortium and COSMIC databases, and none of them were related to the cat's clinicopathological features.

\section{Conclusions}

This study tested two mAbs (trastuzumab and pertuzumab) and an ADC compound (T-DM1) revealing valuable in vitro antiproliferative effects in feline primary (CAT-MT and FCMp) and metastatic (FMCm) cell lines, as well as a conserved cell death mechanism, by apoptosis, comparing to the human breast cancer cell line, SKBR-3. Furthermore, promising synergistic antiproliferative effects were obtained by combining both $\mathrm{mAbs}$ (trastuzumab plus pertuzumab), and mAbs with the TKi, lapatinib, already referred to as a valuable therapeutic protocol for humans. Additionally, mutations found in the clinical samples were never reported as inducing resistance to therapy, in breast cancer patients. Concluding, the use of anti-HER2 mAbs and combined protocols are proposed as a new targeted therapy for cats with different mammary carcinoma subtypes, suggesting that mAbs-resistant FMCs are rare. Still, more studies are needed to produce felinized antiHER2 monoclonal antibodies, preventing cat immune reactions. Moreover, the similarities between the FMC and human breast cancer were demonstrated, reinforcing the utility of the cat as a breast cancer model.

Supplementary Materials: The following are available online at https:/ / www.mdpi.com/article/ 10.3390/cancers13092007/s1, Figure S1: Characterization of the FMC cell lines (CAT-MT, FMCm and FMCP) and the human SKBR-3 cell line, by immunocytochemistry; Table S1: Summary of the characterization of the FMC (CAT-MT, FMCm and FMCP) and human breast cancer (SKBR-3) cell lines, and its origin; Table S2: Analysis of her2 ECD mutations, subdomains II and IV, which encode for the regions recognized by pertuzumab and trastuzumab, respectively, in the feline mammary carcinoma clinical samples; Table S3: Feline cell lines presented a small number of mutations in the feline her 2 ECD, subdomains II (exons 3 and 4) and IV (exons 10 to 13), with none of them reported in humans as leading to resistance to therapy. DNA samples were acquired from cells in culture, and PCR and sequencing were performed with specific primers.

Author Contributions: Conceptualization, A.G. and F.F.; Methodology, A.G. and F.F.; Formal analysis, A.G., C.N. and F.F.; Investigation, A.G., C.N., J.C. and F.F.; Supervision, F.F.; Funding acquisition, F.F.; Project administration, F.F.; Writing — original draft preparation, A.G. and F.F.; Writing-review and editing, A.G., C.N., J.C. and F.F. All authors have read and agreed to the published version of the manuscript. 
Funding: This research was funded by Fundação para a Ciência e a Tecnologia (Portugal) through the projects PTDC/CVT-EPI/3638/2014 and UIDB/00276/2020. A.G. is receipt of a PhD fellowship from Fundação para a Ciência e a Tecnologia (ref. SFRH/BD/132260/2017) and C.N. is receipt of a PhD fellowship from University of Lisbon (ref.C00191r).

Institutional Review Board Statement: Not applicable.

Informed Consent Statement: Samples were collected after informed consent from cat owners with adherence to a high standard (best practice) of veterinary care and in accordance with EU Directive 2010/63/EU and national legislation (DL113/2013).

Data Availability Statement: The datasets used and analyzed in the current study are available from the corresponding author in response to reasonable requests.

Acknowledgments: The authors would like to thank to Raffaella De Maria, University of Turin, Department of Veterinary Sciences, Italy for the CAT-MT cell line, Nobuo Sasaki (DVM, PhD) and Takayuki Nakagawa (DVM, PhD), from Graduate School of Frontier Science, University of Tokyo, Japan, for the FMCm and FMCp cell lines, and Luís Costa, Molecular Medicine Institute, University of Lisbon, Portugal, for the human SKBR-3 cell line. Moreover, we want to thank Fátima Cardoso, Champalimaud Foundation, Lisbon, Portugal for the mAbs and the ADC used in this study, and Filipe Almeida, National Institute of Health Dr. Ricardo Jorge, Lisbon, Portugal for the technical support on the analysis of the cytotoxicity assays.

Conflicts of Interest: The authors declare no conflict of interest. The funders had no role in the design of the study; in the collection, analyses, or interpretation of data; in the writing of the manuscript, or in the decision to publish the results.

\section{References}

1. Soare, G.R.; Soare, C.A. Immunotherapy for Breast Cancer: First FDA Approved Regimen. Discoveries 2019, 7, e91. [CrossRef] [PubMed]

2. Soares, M.; Ribeiro, R.; Najmudin, S.; Gameiro, A.; Rodrigues, R.; Cardoso, F.; Ferreira, F. Serum HER2 levels are increased in cats with mammary carcinomas and predict tissue HER2 status. Oncotarget 2016, 7, 17314-17326. [CrossRef] [PubMed]

3. Soares, M.; Madeira, S.; Correia, J.; Peleteiro, M.; Cardoso, F.; Ferreira, F. Molecular based subtyping of feline mammary carcinomas and clinicopathological characterization. Breast 2016, 27, 44-51. [CrossRef]

4. Soares, M.; Correia, J.; Rodrigues, P.; Simões, M.; Matos, A.; de Ferreira, F. Feline HER2 Protein Expression Levels and Gene Status in Feline Mammary Carcinoma: Optimization of Immunohistochemistry (IHC) and In Situ Hybridization (ISH) Techniques. Microsc. Microanal. 2013, 19, 876-882. [CrossRef] [PubMed]

5. Maniscalco, L.; Iussich, S.; De Las Mulas, J.M.; Millán, Y.; Biolatti, B.; Sasaki, N.; Nakagawa, T.; De Maria, R. Activation of AKT in feline mammary carcinoma: A new prognostic factor for feline mammary tumours. Vet. J. 2012, 191, 65-71. [CrossRef]

6. Millanta, F.; Calandrella, M.; Citi, S.; Della Santa, D.; Poli, A. Overexpression of HER-2 in feline invasive mammary carcinomas: An immunohistochemical survey and evaluation of its prognostic potential. Vet. Pathol. 2005, 42, 30-34. [CrossRef]

7. Michishita, M.; Ohtsuka, A.; Nakahira, R.; Tajima, T.; Nakagawa, T.; Sasaki, N.; Arai, T.; Takahashi, K. Anti-tumor effect of bevacizumab on a xenograft model of feline mammary carcinoma. J. Vet. Med. Sci. 2016, 78, 685-689. [CrossRef]

8. Appert-Collin, A.; Hubert, P.; Crémel, G.; Bennasroune, A. Role of ErbB receptors in cancer cell migration and invasion. Front. Pharmacol. 2015, 6, 1-10. [CrossRef]

9. Sun, Y.; Feng, X.; Qu, J.; Han, W.; Liu, Z.; Li, X.; Zou, M.; Zhen, Y.; Zhu, J. Expression and Characterization of the Extracellular Domain of Human HER2 from Escherichia Coli, and Production of Polyclonal Antibodies Against the Recombinant Proteins. Appl. Biochem. Biotechnol. 2015, 176, 1029-1043. [CrossRef]

10. Witton, C.J.; Reeves, J.R.; Going, J.J.; Cooke, T.G.; Barlett, J.M.S. Expression of the HER1-4 family of receptor tyrosine kinases in breast cancer. J. Pathol. 2003, 200, 290-297. [CrossRef]

11. Ferguson, K.M. Structure-based view of epidermal growth factor receptor regulation. Annu. Rev. Biophys. 2008, 37, 353-373. [CrossRef]

12. De Maria, R.; Olivero, M.; Iussich, S.; Nakaichi, M.; Murata, T.; Biolatti, B.; Flavia, M.; Renzo, D. Spontaneous Feline Mammary Carcinoma Is a Model of HER2 Overexpressing Poor Prognosis Human Breast Cancer. Cancer Res. 2005, 65, 907-912.

13. Santos, S.; Baptista, C.S.; Abreu, R.M.V.; Bastos, E.; Amorim, I.; Gut, I.G.; Gärtner, F.; Chaves, R. ERBB2 in cat mammary neoplasias disclosed a positive correlation between RNA and protein low expression levels: A model for erbB-2 negative human breast cancer. PLoS ONE 2013, 8, 1-17. [CrossRef]

14. Jhanwar-Uniyal, M.; Wainwright, J.V.; Mohan, A.L.; Tobias, M.E.; Murali, R.; Gandhi, C.D.; Schmidt, M.H. Diverse signaling mechanisms of mTOR complexes: mTORC1 and mTORC2 in forming a formidable relationship. Adv. Biol. Regul. 2019, 72, 51-62. [CrossRef] 
15. Oh, D.Y.; Bang, Y.J. HER2-targeted therapies-A role beyond breast cancer. Nat. Rev. Clin. Oncol. 2020, 17, 33-48. [CrossRef] [PubMed]

16. Slamon, D.; Eiermann, W.; Robert, N.; Pienkowski, T.; Martin, M.; Press, M.; Mackey, J.; Glaspy, J.; Chan, A.; Pawlicki, M.; et al. Adjuvant Trastuzumab in HER2-Positive Breast Cancer. N. Engl. J. Med. 2011, 364, 225-237. [CrossRef] [PubMed]

17. Piccart-Gebhart, M.J.; Procter, M.; Leyland-Jones, B.; Goldhirsch, A.; Untch, M.; Smith, I.; Gianni, L.; Baselga, J.; Bell, R.; Jackisch, C.; et al. Trastuzumab after Adjuvant Chemotherapy in HER2-Positive Breast Cancer. N. Engl. J. Med. 2005, 353, 599-609. [CrossRef] [PubMed]

18. Richard, S.; Selle, F.; Lotz, J.P.; Khalil, A.; Gligorov, J.; Grazziotin-Soares, D. Pertuzumab and trastuzumab: The rationale way to synergy. An. Acad. Bras. Cienc. 2016, 88, 565-577. [CrossRef]

19. Klapper, L.N.; Waterman, H.; Sela, M.; Yarden, Y. Tumor-inhibitory antibodies to HER-2/ErbB-2 may act by recruiting c-Cbl and enhancing ubiquitination of HER-2. Cancer Res. 2000, 60, 3384-3388. [PubMed]

20. Valabrega, G.; Montemurro, F.; Aglietta, M. Trastuzumab: Mechanism of action, resistance and future perspectives in HER2overexpressing breast cancer. Ann. Oncol. 2007, 18, 977-984. [CrossRef]

21. Hudis, C.A. Trastuzumab-Mechanism of action and use in clinical practice. N. Engl. J. Med. 2007, 357, 39-51. [CrossRef]

22. Menyhart, O.; Santarpia, L.; Gyorffy, B. A Comprehensive Outline of Trastuzumab Resistance Biomarkers in HER2 Overexpressing Breast Cancer. Curr. Cancer Drug Targets 2015, 15, 665-683. [CrossRef]

23. Mittendorf, E.A.; Wu, Y.; Scaltriti, M.; Meric-Bernstam, F.; Hunt, K.K.; Dawood, S.; Esteva, F.J.; Buzdar, A.U.; Chen, H.; Eksambi, S.; et al. Loss of HER2 amplification following trastuzumab-based neoadjuvant systemic therapy and survival outcomes. Clin. Cancer Res. 2009, 15, 7381-7388. [CrossRef]

24. Scaltriti, M.; Rojo, F.; Ocaña, A.; Anido, J.; Guzman, M.; Cortes, J.; Di Cosimo, S.; Matias-Guiu, X.; Ramon y Cajal, S.; Arribas, J.; et al. Expression of p95HER2, a truncated form of the HER2 receptor, and response to Anti-HER2 therapies in breast cancer. J. Natl. Cancer Inst. 2007, 99, 628-638. [CrossRef]

25. Lipton, A.; Goodman, L.; Leitzel, K.; Cook, J.; Sperinde, J.; Haddad, M.; Köstler, W.J.; Huang, W.; Weidler, J.M.; Ali, S.; et al. HER3, p95HER2, and HER2 protein expression levels define multiple subtypes of HER2-positive metastatic breast cancer. Breast Cancer Res. Treat. 2013, 141, 43-53. [CrossRef]

26. Kataoka, Y.; Mukohara, T.; Shimada, H.; Saijo, N.; Hirai, M.; Minami, H. Association between gain-of-function mutations in PIK3CA and resistance to HER2-targeted agents in HER2-amplified breast cancer cell lines. Ann. Oncol. 2010, 21, 255-262. [CrossRef]

27. Jensen, J.D.; Knoop, A.; Laenkholm, A.V.; Grauslund, M.; Jensen, M.B.; Santoni-Rugiu, E.; Andersson, M.; Ewertz, M. PIK3CA mutations, PTEN, and pHER2 expression and impact on outcome in HER2-positive early-stage breast cancer patients treated with adjuvant chemotherapy and trastuzumab. Ann. Oncol. 2012, 23, 2034-2042. [CrossRef]

28. Nami, B.; Maadi, H.; Wang, Z. Mechanisms underlying the action and synergism of trastuzumab and pertuzumab in targeting HER2-positive breast cancer. Cancers 2018, 10, 342. [CrossRef]

29. Mullen, P.; Cameron, D.A.; Hasmann, M.; Smyth, J.F.; Langdon, S.P. Sensitivity to pertuzumab (2C4) in ovarian cancer models: Cross-talk with estrogen receptor signaling. Mol. Cancer Ther. 2007, 6, 93-100. [CrossRef]

30. Von Minckwitz, G.; Procter, M.; De Azambuja, E.; Zardavas, D.; Benyunes, M.; Viale, G.; Suter, T.; Arahmani, A.; Rouchet, N.; Clark, E.; et al. Adjuvant pertuzumab and trastuzumab in early her2-positive breast cancer. N. Engl. J. Med. 2017, 377, 122-131. [CrossRef]

31. Gerratana, L.; Bonotto, M.; Bozza, C.; Ongaro, E.; Fanotto, V.; Pelizzari, G.; Puglisi, F. Pertuzumab and breast cancer: Another piece in the anti-HER2 puzzle. Expert Opin. Biol. Ther. 2017, 17, 365-374. [CrossRef] [PubMed]

32. Nahta, R. Molecular Mechanisms of Trastuzumab-Based Treatment in HER2-Overexpressing Breast Cancer. ISRN Oncol. 2012, 2012, 1-16. [CrossRef]

33. Yamashita-Kashima, Y.; Shu, S.; Yorozu, K.; Moriya, Y.; Harada, N. Mode of action of pertuzumab in combination with trastuzumab plus docetaxel therapy in a HER2-positive breast cancer xenograft model. Oncol. Lett. 2017, 14, 4197-4205. [CrossRef] [PubMed]

34. Zhang, Y.; Wu, S.; Zhuang, X.; Weng, G.; Fan, J.; Yang, X.; Xu, Y.; Pan, L.; Hou, T.; Zhou, Z.; et al. Identification of an activating mutation in the extracellular domain of HER2 conferring resistance to pertuzumab. Onco Targets. Ther. 2019, 12, 11597-11608. [CrossRef]

35. Gaibar, M.; Beltrán, L.; Romero-Lorca, A.; Fernández-Santander, A.; Novillo, A.; Selli, C. Somatic Mutations in HER2 and Implications for Current Treatment Paradigms in HER2-Positive Breast Cancer. J. Oncol. 2020, 2020, 1-13. [CrossRef]

36. Von Minckwitz, G.; Huang, C.S.; Mano, M.S.; Loibl, S.; Mamounas, E.P.; Untch, M.; Wolmark, N.; Rastogi, P.; Schneeweiss, A.; Redondo, A.; et al. Trastuzumab emtansine for residual invasive HER2-positive breast cancer. N. Engl. J. Med. 2019, 380, 617-628. [CrossRef]

37. Phillips, G.D.L.; Li, G.; Dugger, D.L.; Crocker, L.M.; Parsons, K.L.; Mai, E.; Blättler, W.A.; Lambert, J.M.; Chari, R.V.J.; Lutz, R.J.; et al. Targeting HER2-positive breast cancer with trastuzumab-DM1, an antibody-cytotoxic drug conjugate. Cancer Res. 2008, 68, 9280-9290. [CrossRef]

38. Klute, K.; Nackos, E.; Tasaki, S.; Tagawa, S.T. Microtubule inhibitor-based antibody-Drug conjugates for cancer therapy. Onco. Targets Ther. 2014, 7, 2227-2236. 
39. Barok, M.; Joensuu, H.; Isola, J. Trastuzumab emtansine: Mechanisms of action and drug resistance. Breast Cancer Res. 2014, 16, 3378. [CrossRef]

40. Liu, P.; Fan, J.; Wang, Z.; Zai, W.; Song, P.; Li, Y.; Ju, D. The role of autophagy in the cytotoxicity induced by trastuzumab emtansine (T-DM1) in HER2-positive breast cancer cells. AMB Express 2020, 10, 1-10. [CrossRef]

41. Wang, L.; Wang, Q.; Gao, M.; Fu, L.; Li, Y.; Quan, H.; Lou, L. STAT3 activation confers trastuzumab-emtansine (T-DM1) resistance in HER2-positive breast cancer. Cancer Sci. 2018, 109, 3305-3315. [CrossRef]

42. Sabbaghi, M.A.; Gil-Gomez, G.; Guardia, C.; Servitja, S.; Arpí, O.; García-Alonso, S.; Menendez, S.; Arumi-Uria, M.; Serrano, L.; Salido, M.; et al. Defective cyclin B1 induction in trastuzumab-emtansine (T-DM1) acquired resistance in HER2-positive breast cancer. Clin. Cancer Res. 2017, 23, 7006-7019. [CrossRef]

43. Schroeder, R.L.; Stevens, C.L.; Sridhar, J. Small molecule tyrosine kinase inhibitors of ErbB2/HER2/Neu in the treatment of aggressive breast cancer. Molecules 2014, 19, 15196-15212. [CrossRef]

44. Tóth, G.; Szöőr, Á.; Simon, L.; Yarden, Y.; Szöllősi, J.; Vereb, G. The combination of trastuzumab and pertuzumab administered at approved doses may delay development of trastuzumab resistance by additively enhancing antibody-dependent cell-mediated cytotoxicity. $m A$ bs 2016, 8, 1361-1370. [CrossRef]

45. Nahta, R.; Hung, M.C.; Esteva, F.J. The HER-2-Targeting Antibodies Trastuzumab and Pertuzumab Synergistically Inhibit the Survival of Breast Cancer Cells. Cancer Res. 2004, 64, 2343-2346. [CrossRef] [PubMed]

46. Harbeck, N.; Beckmann, M.W.; Rody, A.; Schneeweiss, A.; Müller, V.; Fehm, T.; Marschner, N.; Gluz, O.; Schrader, I.; Heinrich, G.; et al. HER2 dimerization inhibitor pertuzumab-Mode of action and clinical data in breast cancer. Breast Care 2013, 8, 49-55. [CrossRef] [PubMed]

47. Canonici, A.; Ivers, L.; Conlon, N.T.; Pedersen, K.; Gaynor, N.; Browne, B.C.; O’Brien, N.A.; Gullo, G.; Collins, D.M.; O’Donovan, N.; et al. HER-targeted tyrosine kinase inhibitors enhance response to trastuzumab and pertuzumab in HER2-positive breast cancer. Investig. New Drugs 2019, 37, 441-451. [CrossRef]

48. Watson, S.S.; Dane, M.; Chin, K.; Tatarova, Z.; Liu, M.; Liby, T.; Thompson, W.; Smith, R.; Nederlof, M.; Bucher, E.; et al. Microenvironment-Mediated Mechanisms of Resistance to HER2 Inhibitors Differ between HER2+ Breast Cancer Subtypes. Cell Syst. 2018, 6, 329-342.e6. [CrossRef]

49. Okita, R.; Uhiko Shimizu, K.; Nojima, Y.; Yukawa, T.; Maeda, A.; Saisho, S.; Nakata, M. Lapatinib enhances trastuzumab-mediated antibody-dependent cellular cytotoxicity via upregulation of HER2 in malignant mesothelioma cells. Oncol. Rep. 2015, 34, 2864-2870. [CrossRef]

50. Cheung, K.L. Treatment strategies and survival outcomes in breast cancer. Cancers 2020, 12, 735. [CrossRef]

51. Maniscalco, L.; Millan, Y.; Iussich, S.; Denina, M.; Sanchez-Cespedes, R.; Gattino, F.; Biolatti, B.; Sasaki, N.; Nakagawa, T.; Di Renzo, M.F.; et al. Activation of mammalian target of rapamycin (mTOR) in triple negative feline mammary carcinomas. $B M C$ Vet. Res. 2013, 9, 1-9. [CrossRef]

52. Almeida, F.; Gameiro, A.; Correia, J.; Ferreira, F. Histone Deacetylase Inhibitors and Microtubule Inhibitors Induce Apoptosis in Feline Luminal Mammary Carcinoma Cells. Animals 2021, 11, 502. [CrossRef]

53. Wolff, A.C.; Hammond, M.E.H.; Hicks, D.G.; Dowsett, M.; McShane, L.M.; Allison, K.H.; Allred, D.C.; Bartlett, J.M.S.; Bilous, M.; Fitzgibbons, P.; et al. Recommendations for human epidermal growth factor receptor 2 testing in breast. J. Clin. Oncol. 2013, 31, 3997-4013. [CrossRef] [PubMed]

54. Santos, S.; Sá, D.; Bastos, E.; Guedes-Pinto, H.; Gut, I.; Gärtner, F.; Chaves, R. An efficient protocol for genomic DNA extraction from formalin-fixed paraffin-embedded tissues. Res. Vet. Sci. 2009, 86, 421-426. [CrossRef]

55. Ferreira, D.; Soares, M.; Correia, J.; Adega, F.; Ferreira, F.; Chaves, R. Assessment of ERBB2 and TOP2agene statusand expression profilein feline mammary tumors: Findings and guidelines. Aging 2019, 11, 4688-4705. [CrossRef] [PubMed]

56. Hall, T.A. BioEdit: A User-Friendly Biological Sequence Alignment Editor and Analysis Program for Windows 95/98/NT. Nucleic Acids Symp. Ser. 1999, 41, 95-98.

57. Stucky, B.J. Seqtrace: A graphical tool for rapidly processing DNA sequencing chromatograms. J. Biomol. Tech. 2012, 23, 90-93. [CrossRef]

58. Porrello, A.; Cardelli, P.; Spugnini, E.P. Oncology of companion animals as a model for humans. An overview of tumor histotypes. J. Exp. Clin. Cancer Res. 2006, 25, 97-105.

59. Gearing, D.P.; Huebner, M.; Virtue, E.R.; Knight, K.; Hansen, P.; Lascelles, B.D.X.; Gearing, R.P.; Drew, A.C. In Vitro and In Vivo Characterization of a Fully Felinized Therapeutic Anti-Nerve Growth Factor Monoclonal Antibody for the Treatment of Pain in Cats. J. Vet. Intern. Med. 2016, 30, 1129-1137. [CrossRef]

60. Enomoto, M.; Mantyh, P.W.; Murrell, J.; Innes, J.F.; Lascelles, B.D.X. Anti-nerve growth factor monoclonal antibodies for the control of pain in dogs and cats. Vet. Rec. 2019, 184, 1-14. [CrossRef]

61. Hegde, P.S.; Rusnak, D.; Bertiaux, M.; Alligood, K.; Strum, J.; Gagnon, R.; Gilmer, T.M. Delineation of molecular mechanisms of sensitivity to lapatinib in breast cancer cell lines using global gene expression profiles. Mol. Cancer Ther. 2007, 6, 1629-1640. [CrossRef]

62. Zhang, Y.; Zhang, J.; Liu, C.; Du, S.; Feng, L.; Luan, X.; Zhang, Y.; Shi, Y.; Wang, T.; Wu, Y.; et al. Neratinib induces ErbB2 ubiquitylation and endocytic degradation via HSP90 dissociation in breast cancer cells. Cancer Lett. 2016, 382, 176-185. [CrossRef] [PubMed] 
63. Gameiro, A.; Almeida, F.; Nascimento, C.; Correia, J. Tyrosine Kinase Inhibitors Are Promising Therapeutic Tools for Cats with HER2-Positive Mammary Carcinoma. Pharmaceutics 2021, 13, 346. [CrossRef]

64. Bonkobara, M. Dysregulation of tyrosine kinases and use of imatinib in small animal practice. Vet. J. 2015, 205, 180-188. [CrossRef]

65. Henson, E.S.; Hu, X.; Gibson, S.B. Herceptin sensitizes ErbB2-overexpressing cells to apoptosis by reducing antiapoptotic Mcl-1 expression. Clin. Cancer Res. 2006, 12, 845-853. [CrossRef] [PubMed]

66. Mohsin, S.K.; Weiss, H.L.; Gutierrez, M.C.; Chamness, G.C.; Schiff, R.; DiGiovanna, M.P.; Wang, C.X.; Hilsenbeck, S.G.; Osborne, C.K.; Allred, D.C.; et al. Neoadjuvant trastuzumab induces apoptosis in primary breast cancers. J. Clin. Oncol. 2005, 23, 2460-2468. [CrossRef] [PubMed]

67. Zhang, X.; Chen, J.; Weng, Z.; Li, Q.; Zhao, L.; Yu, N.; Deng, L.; Xu, W.; Yang, Y.; Zhu, Z.; et al. A new anti-HER2 antibody that enhances the anti-tumor efficacy of trastuzumab and pertuzumab with a distinct mechanism of action. Mol. Immunol. 2020, 119, 48-58. [CrossRef] [PubMed]

68. Hofstaedter, F.; Vollmann, A.; Diermeier, S.; Brockhoff, G.; Heckel, B. Differential impact of Cetuximab, Pertuzumab and Trastuzumab on BT474 and SK-BR-3 breast cancer cell proliferation. Cell Prolif. 2007, 49, 488-507.

69. Yao, H.; He, G.; Yan, S.; Chen, C.; Song, L.; Rosol, T.J.; Deng, X. Triple-negative breast cancer: Is there a treatment on the horizon? Oncotarget 2017, 8, 1913-1924. [CrossRef]

70. Burguin, A.; Furrer, D.; Ouellette, G.; Jacob, S.; Diorio, C.; Durocher, F. Trastuzumab effects depend on HER2 phosphorylation in HER2-negative breast cancer cell lines. PLOS ONE 2020, 15, 1-17. [CrossRef] [PubMed]

71. Weigelt, B.; Lo, A.T.; Park, C.C.; Gray, J.W.; Bissell, M.J. HER2 signaling pathway activation and response of breast cancer cells to HER2-targeting agents is dependent strongly on the 3D microenvironment. Breast Cancer Res. Treat. 2010, 122, 35-43. [CrossRef]

72. Diermeier-Daucher, S.; Breindl, S.; Buchholz, S.; Ortmann, O.; Brockhoff, G. Modular anti-EGFR and anti-Her2 targeting of SK-BR-3 and BT474 breast cancer cell lines in the presence of ErbB receptor-specific growth factors. Cytom. Part A 2011, 79, 684-693. [CrossRef]

73. Franklin, M.C.; Carey, K.D.; Vajdos, F.F.; Leahy, D.J.; De Vos, A.M.; Sliwkowski, M.X. Insights into ErbB signaling from the structure of the ErbB2-pertuzumab complex. Cancer Cell 2004, 5, 317-328. [CrossRef]

74. Metzger-Filho, O.; Winer, E.P.; Krop, I. Pertuzumab: Optimizing HER2 blockade. Clin. Cancer Res. 2013, 19, 5552-5556. [CrossRef] [PubMed]

75. Agus, D.B.; Akita, R.W.; Fox, W.D.; Lewis, G.D.; Higgins, B.; Pisacane, P.I.; Lofgren, J.A.; Tindell, C.; Evans, D.P.; Maiese, K.; et al. Targeting ligand-activated ErbB2 signaling inhibits breast and prostate tumor growth. Cancer Cell 2002, 2, 127-137. [CrossRef]

76. Li, J.; Ma, M.; Yang, X.; Zhang, M.; Luo, J.; Zhou, H.; Huang, N.; Xiao, F.; Lai, B.; Lv, W.; et al. Circular HER2 RNA positive triple negative breast cancer is sensitive to Pertuzumab. Mol. Cancer 2020, 19, 142. [CrossRef]

77. Lambert, J.M.; Chari, R.V.J. Ado-trastuzumab emtansine (T-DM1): An antibody-drug conjugate (ADC) for HER2-positive breast cancer. J. Med. Chem. 2014, 57, 6949-6964. [CrossRef] [PubMed]

78. Endo, Y.; Takeda, K.; Mohan, N.; Shen, Y.; Jiang, J.; Rotstein, D.; Wu, W.J. Payload of T-DM1 binds to cell surface cytoskeletonassociated protein 5 to mediate cytotoxicity of hepatocytes. Oncotarget 2018, 9, 37200-37215. [CrossRef]

79. Nagayama, A.; Neelima, V.; Leif, E.; Bardia, A. Novel antibody-drug conjugates for triple negative breast cancer Aiko. Ther. Adv. Med. Oncol. 2020, 12, 1-12. [CrossRef]

80. Barok, M.; Tanner, M.; Köninki, K.; Isola, J. Trastuzumab-DM1 causes tumour growth inhibition by mitotic catastrophe in trastuzumab-resistant breast cancer cells in vivo. Breast Cancer Res. 2011, 13, 1-11. [CrossRef] [PubMed]

81. Januszyk, M.; Rennert, R.; Sorkin, M.; Maan, Z.; Wong, L.; Whittam, A.; Whitmore, A.; Duscher, D.; Gurtner, G. Evaluating the Effect of Cell Culture on Gene Expression in Primary Tissue Samples Using Microfluidic-Based Single Cell Transcriptional Analysis. Microarrays 2015, 4, 540-550. [CrossRef]

82. Zaitseva, M.; Vollenhoven, B.J.; Rogers, P.A.W. In vitro culture significantly alters gene expression profiles and reduces differences between myometrial and fibroid smooth muscle cells. Mol. Hum. Reprod. 2006, 12, 187-207. [CrossRef]

83. Tatara, T.; Mukohara, T.; Tanaka, R.; Shimono, Y.; Funakoshi, Y.; Imamura, Y.; Toyoda, M.; Kiyota, N.; Hirai, M.; Kakeji, Y.; et al. 3D Culture Represents Apoptosis Induced by Trastuzumab Better than 2D Monolayer Culture. Anticancer Res. 2018, 38, $2831-2839$.

84. Hui-Wen Lo, R.L.C. Regulation of Apoptosis by HER2 in Breast Cancer. J. Carcinog. Mutagen. 2013, 2013. [CrossRef]

85. Poon, I.K.H.; Hulett, M.D.; Parish, C.R. Molecular mechanisms of late apoptotic/necrotic cell clearance. Cell Death Differ. 2010, 17, 381-397. [CrossRef] [PubMed]

86. Tsang, R.Y.; Finn, R.S. Beyond trastuzumab: Novel therapeutic strategies in HER2-positive metastatic breast cancer. Br. J. Cancer 2012, 106, 6-13. [CrossRef] [PubMed]

87. Liu, T.; Yacoub, R.; Taliaferro-Smith, L.D.; Sun, S.-Y.; Graham, T.R.; Dolan, R.; Lobo, C.; Tighiouart, M.; Yang, L.; Adams, A.; et al. Combinatorial Effects of Lapatinib and Rapamycin in Triple-Negative Breast Cancer Cells. Mol. Cancer Ther. 2011, 10, 1460-1469. [CrossRef] [PubMed]

88. Watanabe, S.; Yonesaka, K.; Tanizaki, J.; Nonagase, Y.; Takegawa, N.; Haratani, K.; Kawakami, H.; Hayashi, H.; Takeda, M.; Tsurutani, J.; et al. Targeting of the HER2/HER3 signaling axis overcomes ligand-mediated resistance to trastuzumab in HER2-positive breast cancer. Cancer Med. 2019, 8, 1258-1268. [CrossRef]

89. Wehrman, T.S.; Raab, W.J.; Casipit, C.L.; Doyonnas, R.; Pomerantz, J.H.; Blau, H.M. A system for quantifying dynamic protein interactions defines a role for Herceptin in modulating ErbB2 interactions. Proc. Natl. Acad. Sci. USA 2006, 103, 19063-19068. [CrossRef] 
90. Lu, Y.; Zi, X.; Zhao, Y.; Mascarenhas, D.; Pollak, M. Insulin-Like Growth Factor-I Receptor Signaling and Resistance to Trastuzumab (Herceptin). J. Natl. Cancer Inst. 2001, 93, 1852-1857. [CrossRef]

91. Agarwal, S.; Zerillo, C.; Kolmakova, J.; Christensen, J.G.; Harris, L.N.; Rimm, D.L.; Digiovanna, M.P.; Stern, D.F. Association of constitutively activated hepatocyte growth factor receptor (Met) with resistance to a dual EGFR/Her2 inhibitor in non-small-cell lung cancer cells. Br. J. Cancer 2009, 100, 941-949. [CrossRef]

92. Nagata, Y.; Lan, K.H.; Zhou, X.; Tan, M.; Esteva, F.J.; Sahin, A.A.; Klos, K.S.; Li, P.; Monia, B.P.; Nguyen, N.T.; et al. PTEN activation contributes to tumor inhibition by trastuzumab, and loss of PTEN predicts trastuzumab resistance in patients. Cancer Cell 2004, 6, 117-127. [CrossRef] [PubMed]

93. Gagliato, D.D.M.; Leonardo, D.; Jardim, F.; Pereira, M.S.; Hortobagyi, G.N. Mechanisms of resistance and sensitivity to anti-HER2 therapies in HER2 + breast cancer Introduction: Pathways to Trastuzumab. Oncotarget 2016, 7, 64431. [CrossRef] [PubMed]

94. Hutcheson, I.; Barrow, D.; Hasmann, M.; Nicholson, R. Induction of erbB3/EGFR heterodimers mediates resistance to pertuzumab in a tamoxifen-resistant MCF-7 breast cancer cell line. In Proceedings of the AACR-NCI-EORTC International Conference, San Francisco, CA, USA, 22-26 October 2007.

95. Stanley, A.; Ashrafi, G.H.; Seddon, A.M.; Modjtahedi, H. Synergistic effects of various Her inhibitors in combination with IGF-1R, C-MET and Src targeting agents in breast cancer cell lines. Sci. Rep. 2017, 7, 3964. [CrossRef] [PubMed]

96. Xu, Z.Q.; Zhang, Y.; Li, N.; Liu, P.J.; Gao, L.; Gao, X.; Tie, X.J. Efficacy and safety of lapatinib and trastuzumab for HER2-positive breast cancer: A systematic review and meta-analysis of randomised controlled trials. BMJ Open 2017, 7, 1-9. [CrossRef] [PubMed]

97. Scaltriti, M.; Verma, C.; Guzman, M.; Jimenez, J.; Parra, J.L.; Pedersen, K.; Smith, D.J.; Landolfi, S.; y Cajal, S.R.; Arribas, J.; et al. Lapatinib, a HER2 tyrosine kinase inhibitor, induces stabilization and accumulation of HER2 and potentiates trastuzumabdependent cell cytotoxicity. Oncogene 2009, 28, 803-814. [CrossRef]

98. Blackwell, K.L.; Zaman, K.; Qin, S.; Tkaczuk, K.H.R.; Campone, M.; Hunt, D.; Bryce, R.; Goldstein, L.J. Neratinib in Combination with Trastuzumab for the Treatment of Patients with Advanced HER2-positive Breast Cancer: A Phase I/II Study. Clin. Breast Cancer 2019, 19, 97-104.e4. [CrossRef]

99. Mishra, R.; Hanker, A.B.; Garrett, J.T. Genomic alterations of ERBB receptors in cancer: Clinical implications. Oncotarget 2017, 8, 114371-114392. [CrossRef]

100. Rajasekaran, R.; Doss, C.G.P.; Sudandiradoss, C.; Ramanathan, K.; Purohit, R.; Sethumadhavan, R. Effect of deleterious nsSNP on the HER2 receptor based on stability and binding affinity with herceptin: A computational approach. Comptes Rendus Biol. 2008, 331, 409-417. [CrossRef]

101. Hyman, D.M.; Piha, S.A.-P.; Won, H.; Rodon, J.; Saura, C.; Shapiro, G.I.; Juric, D.; Quinn, D.I.; Moreno, V.; Doger, B.; et al. HER kinase inhibition in patients with HER2-and HER3-mutant cancers. Nature 2018, 554, 189-194. [CrossRef]

102. Connell, C.M.; Doherty, G.J. Activating HER2 mutations as emerging targets in multiple solid cancers. ESMO Open 2017, 2, 1-11. [CrossRef] [PubMed] 